Nat. Hazards Earth Syst. Sci., 18, 1825-1847, 2018

https://doi.org/10.5194/nhess-18-1825-2018

(C) Author(s) 2018. This work is distributed under

the Creative Commons Attribution 4.0 License.

\title{
Linking source with consequences of coastal storm impacts for climate change and risk reduction scenarios for Mediterranean sandy beaches
}

\author{
Marc Sanuy $^{1}$, Enrico Duo ${ }^{2}$, Wiebke S. Jäger ${ }^{3}$, Paolo Ciavola ${ }^{2}$, and José A. Jiménez ${ }^{1}$ \\ ${ }^{1}$ Laboratori d'Enginyeria Marítima, Universitat Politècnica de Catalunya Barcelona Tech, Barcelona, \\ Jordi Girona 1-3, 08034, Spain \\ ${ }^{2}$ Department of Physics and Earth Science, University of Ferrara, Via Saragat 1, Ferrara, 44122, Italy \\ ${ }^{3}$ Department of Hydraulic Engineering, Delft University of Technology, Stevinweg 1, Delft, 2628 CN, the Netherlands
}

Correspondence: Marc Sanuy (marc.sanuy@upc.edu)

Received: 29 September 2017 - Discussion started: 9 October 2017

Revised: 16 May 2018 - Accepted: 23 May 2018 - Published: 3 July 2018

\begin{abstract}
Integrated risk assessment approaches to support coastal managers' decisions when designing plans are increasingly becoming an urgent need. To enable efficient coastal management, possible present and future scenarios must be included, disaster risk reduction measures integrated, and multiple hazards dealt with. In this work, the Bayesian network-based approach to coastal risk assessment was applied and tested at two Mediterranean sandy coasts (Tordera Delta in Spain and Lido degli Estensi-Spina in Italy). Process-oriented models are used to predict hazards at the receptor scale which are converted into impacts through vulnerability relations. In each site, results from 96 simulations under different scenarios are integrated by using a Bayesian-based decision network to link forcing characteristics with expected impacts through conditional probabilities. Consultations with local stakeholders and experts have shown that the tool is valuable for communicating risks and the effects of risk reduction strategies. The tool can therefore be valuable support for coastal decision-making.
\end{abstract}

\section{Introduction}

Increasing coastal risk due to the intensification of hazard and exposure magnitudes (IPCC, 2012, 2013) is driving the needs of coastal managers towards more innovative approaches for coastal risk assessment and management. At the international and European levels these needs are high- lighted by the impact of recent extreme events such as Hurricane Katrina in Louisiana in 2005 (Beven II et al., 2008), storm Xynthia in France in 2010 (Bertin et al., 2012; Kolen et al., 2013), Hurricane Sandy in New York in 2012 (Kunz et al., 2013; Van Verseveld et al., 2015), and the southern North Sea storm in 2013 (Spencer et al., 2015). Similarly, in the Mediterranean, several extreme events have impacted coastal communities at the local and regional levels such as storm Klaus in 2009, as described in Bertotti et al. (2012), and cyclogenesis mechanisms in the NW Mediterranean described in Trigo et al. (2002). In this context, the coasts of Catalunya (Spain) and Emilia-Romagna (Italy) also recently experienced coastal storm impacts that caused socioeconomic losses (Jiménez et al., 2012; Perini et al., 2015; Harley et al., 2016; Trembanis et al., 2017).

Therefore, coastal managers must properly deal with coastal risk when designing management plans. This is recognised in several initiatives such as the protocol of Integrated Coastal Zone Management (ICZM) for the Mediterranean, which includes a chapter on natural hazards and advises signed parties to implement vulnerability and risk assessments. In addition, the EU Floods Directive is another example dealing specifically with floods. Therefore, the need for integrated decision support systems based on modern approaches for coastal risk assessment is increasing. Coping with storm-induced risks in coastal areas involves testing multiple risk reduction measures against multiple forcing conditions in current and future scenarios considering climate change. 
The literature provides different approaches with which to implement these assessments. It is becoming increasingly important to consider multi-hazard approaches when assessing risk at all levels (i.e. from the regional to local scales). Therefore, the scientific community provides integrated and interdisciplinary approaches (e.g. Ciavola et al., 2011a, b; Penning-Rowsell et al., 2014; Vojinovic et al., 2014; Oumeraci et al., 2015; Van Dongeren et al., 2018). Up-to-date methodologies can be used in coastal risk assessments at different scales ranging from regional (up to hundreds of kilometres) to local assessments (up to $10 \mathrm{~km}$ ). Regional methodologies aim to locate coastal sectors more sensitive to impacts, the so-called hotspots. Local approaches aim to achieve the highest possible level of accuracy for risk evaluation and to support decision-making for previously identified hotspots. Notably, coastal risk assessments must include physical concepts to characterise physical phenomena (i.e. the source of the hazard) and socioeconomic concepts to describe the impact of the physical phenomena on human assets (i.e. the consequences). A conceptual flexible framework that can capture all aspects of coastal risk assessment is the source-pathway-receptor-consequence (SPRC) model (e.g. Narayan et al., 2014; Zanuttigh et al., 2014; Oumeraci et al., 2015).

When addressing the problem at the local scale, it is necessary to accurately predict the impact and reproduce in detail coastal hazards. The analysis of physical impacts is regularly implemented with process-based numerical models providing detailed information for areas prone to multiple hazards (e.g. Roelvink et al., 2009; McCall et al., 2010; Harley et al., 2011; Roelvink and Reniers, 2012). However, multiple forcing conditions acting at the site and under different scenarios must be evaluated. Bayesian network-based (BN) approaches have demonstrated their versatility and utility in efficiently combining multiple variables to predict system behaviour for multiple hypotheses (e.g. Plant et al., 2016). The data assimilation capacity of $\mathrm{BN}$ approaches allows integrating many multi-hazard simulations from process-oriented models for joint assessment of different scenarios and alternatives (e.g. Gutierrez et al., 2011; Poelhekke et al., 2016), including also socioeconomic concepts (e.g. Van Verseveld et al., 2015). This is an advantage compared to classical GIS-based approaches, which are more limited when combining large number of simulations in multiple subsets of scenarios.

Jäger et al. (2018) proposed the conceptual BN framework used in this work, which is based on the integration of the SPRC and was developed in the RISC-KIT EU FP7 project (Van Dongeren et al., 2018), where it was used as a Bayesianbased decision network (BDN). Plomaritis et al. (2018) applied the framework to test its potential as an early warning system and the response of risk reduction measures in Ria Formosa (Portugal). In this paper, the authors describe the application of the framework adapted to select and compare strategic alternatives to reduce coastal risk in current and projected future climate scenarios. The application was con- ducted at two sedimentary coasts in the Mediterranean environment, namely the Tordera Delta for the Catalan coast (Spain) and the Lido degli Estensi-Spina for the EmiliaRomagna coast (Italy). At both study sites, the tested measures were pre-selected taking into account the outcome of interviews to stakeholders (see Martinez et al., 2018) and obtained results were used in a participatory process to select acceptable measures on the basis of a multi-criteria analysis (see Barquet and Cumiskey, 2018).

\section{Regional contexts and case studies}

The two presented case study sites are representative of many other coastal areas in the Mediterranean consisting of sandy beaches where local economic activities are based on the tourist sector. These areas are characterised by urbanisation and infrastructural growth close to the shoreline (limiting natural beach accommodation processes) and economic activities located on the beach and immediate first part of the hinterland (e.g. concessions, campsites, restaurants). The coast keeps offering its recreational function, but loses its protective function against storms. In addition, the hinterland is exposed to storm-induced hazards.

\subsection{Tordera Delta, Catalunya (Spain)}

The Catalan coast is located in the NW Mediterranean Sea (Fig. 1a1). It consists of a coastline $600 \mathrm{~km}$ long with about $280 \mathrm{~km}$ of beaches. Coastal damage has increased during the last decades as a result of the increasing exposure along the coastal zone and progressive narrowing of existing beaches (Jiménez et al., 2012) through dominant erosive behaviour due to net littoral drift (Jiménez et al., 2011). Locations experiencing storm-induced problems are present along the entire coastline and are especially concentrated in areas experiencing the largest decadal-scale shoreline erosion rates. Among these areas, the Tordera Delta, located about $50 \mathrm{~km}$ north of Barcelona, provides a good example (Jiménez et al., 2018) (Fig. 2).

The deltaic coast is composed of a coarse sandy coastline extending about $5 \mathrm{~km}$ from S'Abanell beach at the northern end and Malgrat de Mar beach in the south (see Fig. 2). This zone is highly dynamic and is currently in retreat because of the net long-shore sediment transport directed southwest and the decrease in Tordera river sediment supplies. Consequently, the beaches surrounding the river mouth, which were traditionally stable or accreting, are being significantly eroded (Jiménez et al., 2011; Sardá et al., 2013). As a result of the progressive narrowing of the beach in the area, the frequency of inundation episodes and damage to existing infrastructure (beach promenade, campsite installations, desalination plant infrastructure, roads) has significantly increased since the beginning of the 1990s (Jiménez et al., 2011; Sardá et al., 2013) (Fig. 2). 


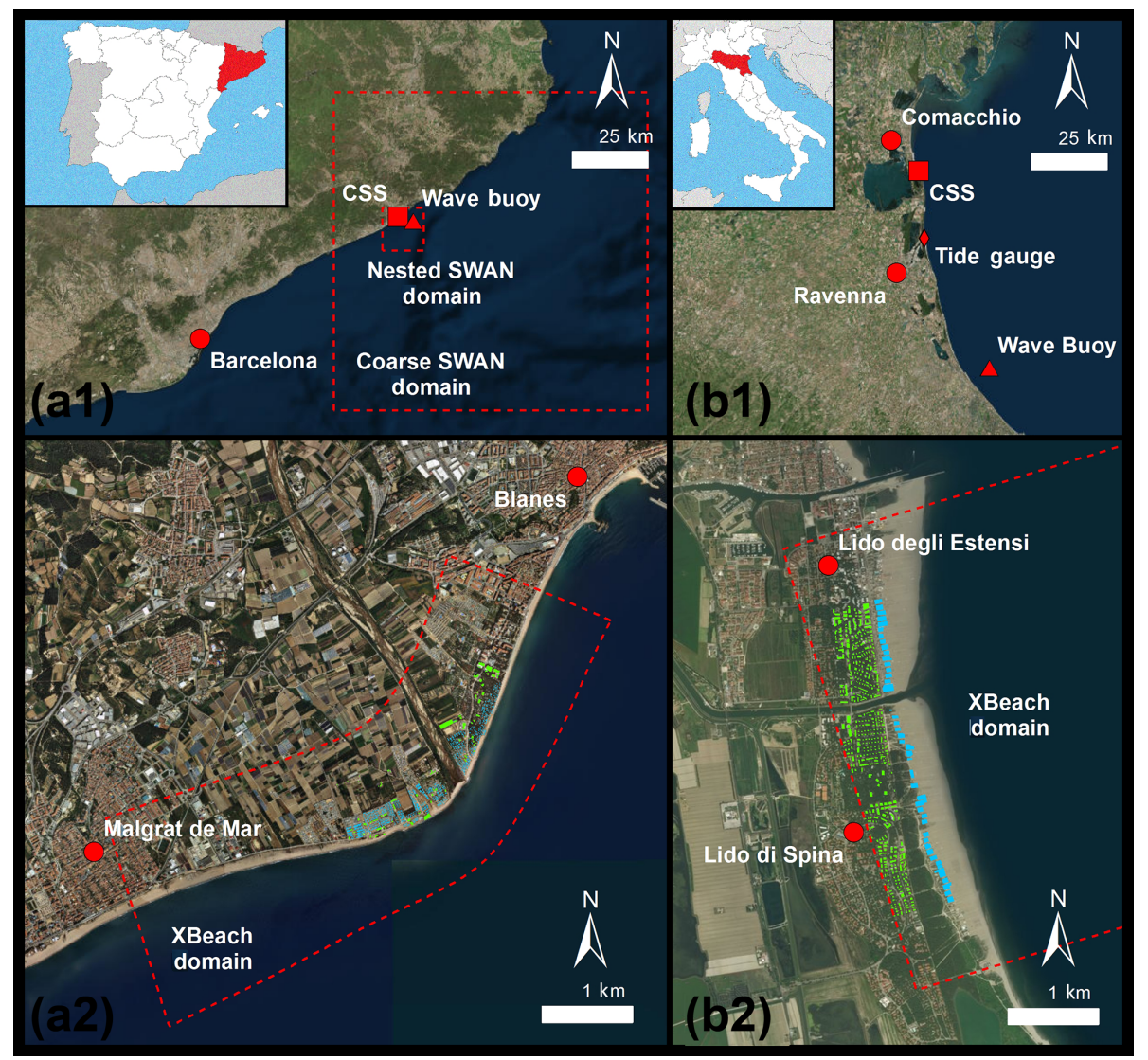

Figure 1. Regional and local contexts: (a1) central-northern Catalan coast; (b1) Emilia-Romagna coast; (a2) local hotspot of Tordera Delta; (b2) local hotspots of Lido degli Estensi-Spina. The main locations (red dots), wave buoys (red triangles), tide gauge (red diamond), and the case study sites (red squares). The domains of the large-scale and local models (dashed red lines) are highlighted for each box.

Subsequently, existing campsites in the most affected zones have abandoned the areas closer to the shoreline, as in many cases, those are fully eroded or directly exposed to wave action. In other cases, owners have tried to implement local protection measures that in many cases have enhanced existing erosion (Jiménez et al., 2018).

Coastal storms in the Catalan Sea can be defined as events during which the significant wave height (Hs) exceeds a threshold of $2 \mathrm{~m}$ for a minimum duration of $6 \mathrm{~h}$ (Mendoza et al., 2011). Despite this, not all storms can be considered as hazardous events in terms of induced inundation and/or erosion. Mendoza et al. (2011) developed a five-category storm classification for typical conditions in the Catalan Sea based on their power content. The classification seems to well represent the behaviour of storm events in the Mediterranean and was successfully employed in the Northern Adriatic (Armaroli et al., 2012). Furthermore, Mendoza et al. (2011) estimated the expected order of magnitude of induced coastal hazards (erosion and inundation) for each class and beach characteristics along the Catalan coast. According to their results, storms from category III $(\mathrm{Hs}=3.5 \mathrm{~m}$, duration around $50 \mathrm{~h})$ to $\mathrm{V}(\mathrm{Hs}=6 \mathrm{~m}$, duration longer than $100 \mathrm{~h})$ are most likely to cause significant damages. One important aspect to consider is that wave-induced run-up (setup + swash) is the largest contribution to overwash at the beach during storm events, because the magnitude of surges along the Catalan coast is relatively low (Mendoza and Jiménez, 2008).

\subsection{Lido degli Estensi-Spina, Emilia-Romagna (Italy)}

The Emilia-Romagna (Italy) coast is located in the northern part of the Adriatic Sea (Fig. 1b1). The coast is about $130 \mathrm{~km}$ long and characterised by low-lying, predominantly dissipative sandy beaches. The coastal corridor has low elevations, mainly ranging from -2 to $3 \mathrm{ma}$ a.m.s.l. (Regione Emilia-Romagna, 2010). The area alternates between highly urbanised touristic zones and natural areas with dunes, which are often threatened by flooding and erosion (Regione Emilia-Romagna, 2010). The impact of coastal erosion was emphasised by subsidence due to water and gas extraction over the last century, especially in the Ravenna area (Taramelli et al., 2015), a decrease in riverine sediment transport because of the strong human influence on rivers and their basins (Preciso et al., 2012), and the reforestation of the Apennines (Billi and Rinaldi, 1997). Touristic activities 


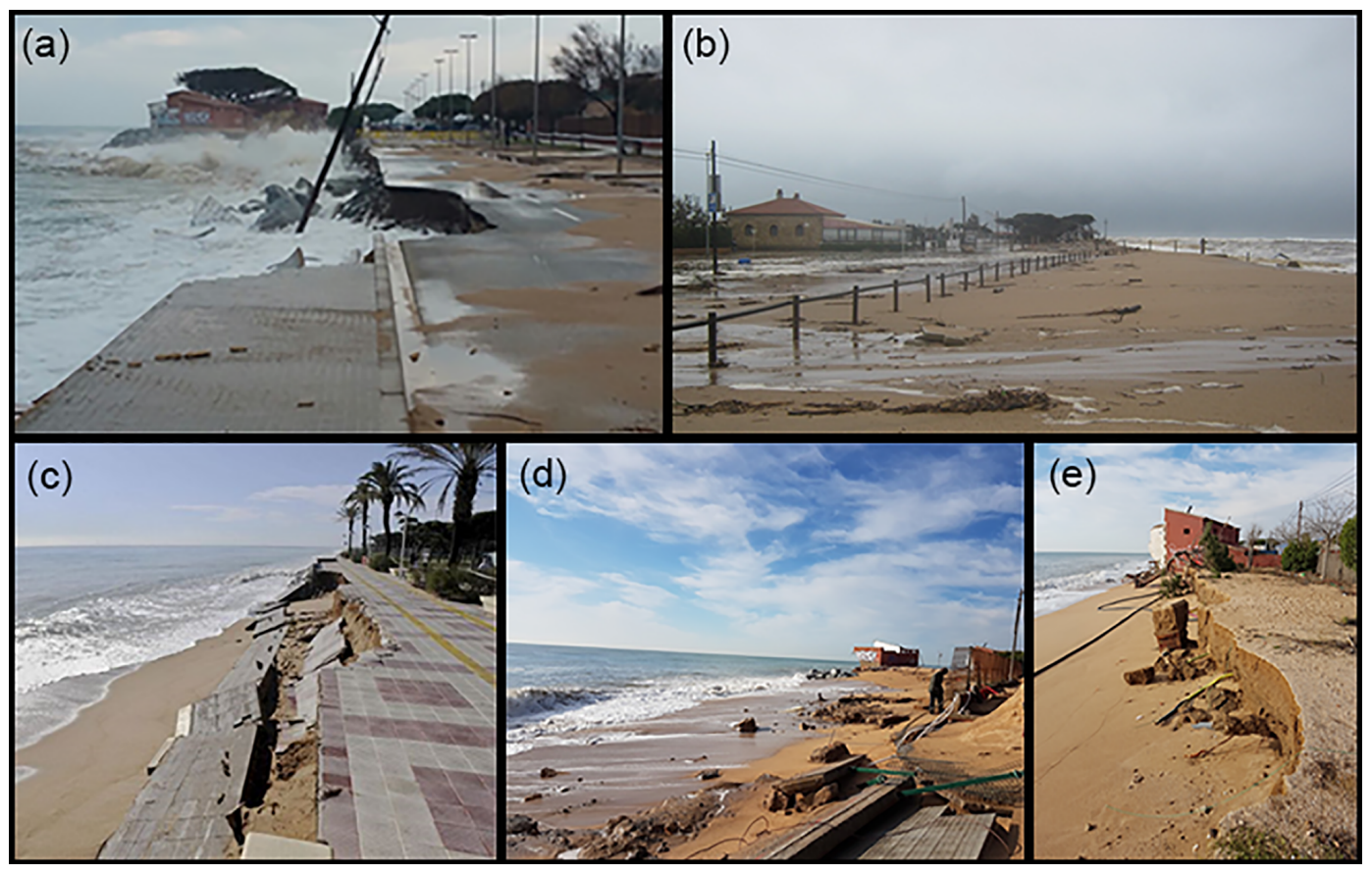

Figure 2. Impacts on the Tordera Delta. Destruction of a road at Malgrat (a); overwash at campsites north of the river mouth (b); destruction of the promenade north of the river mouth (c); beach erosion and damage to utilities and buildings at Malgrat (d, e).

(accommodation, food service, beach services) can be considered main drivers of the coastal economy. Beach concessions, which provide beach and food services, have grown exponentially in number since the second half of the last century, with negative consequences on natural areas, as in the province of Ravenna (Sytnik and Stecchi, 2014). To protect the coast and its assets from the impacts of flooding and erosion, regional managers have constructed hard defences (e.g. emerged and submerged breakwaters, groins, rubble mounds; Regione Emilia-Romagna, 2010) along the entire regional coast (over $60 \%$ of the coast is protected) and regularly implement restorative nourishment plans.

During the last decades, several EU projects such as Theseus (www.theseusproject.eu, last access: May 2018) and MICORE (www.micore.eu, last access: May 2018) provided a good understanding of hydro-morphodynamics and risks to the coast. These projects and works published in the international literature such as Ciavola et al. (2007), Armaroli et al. (2009, 2012), and Perini et al. (2016) were the product of strong collaboration between scientists and regional managers (Servizio Geologico Sismico e dei Suoli, SGSS). This led to the compilation and implementation of a storm database (Perini et al., 2011) and a regional early warning system (Harley et al., 2016). The RISC-KIT project (www.risckit.eu, last access: May 2018) provided additional knowledge on this coastal area. The areas most exposed to coastal risk are well known, as can be seen in the works of Perini et al. (2016) and Armaroli and Duo (2018).
For a more local perspective, the Lido degli Estensi-Spina coastline (Comacchio municipality, Ferrara province, Italy) area represents a highly touristic stretch of coast with concessions directly facing the sea (Fig. 1b2). The littoral drift is northward as confirmed by the width of the sandy beaches, which increases from 20 to $50 \mathrm{~m}$ in the southern part of Lido di Spina to 200 to $300 \mathrm{~m}$ in the northern part of Lido degli Estensi. Here the sediment is trapped by the groin of the mouth of a navigation canal (Porto Canale). The beach is not protected, and regional managers implement regular nourishment in the southern part of the area (Nordstrom et al., 2015). At the back of the concessions, the villages accommodate restaurants and hotels for tourists, along with residential buildings (mainly holiday houses). In a recent study, Bertoni et al. (2015) analysed aerial photographs of the evolution of the case study area, focusing on the stretch of coast between Porto Garibaldi and the Reno river mouth. The area was impacted by the event in February 2015 (see Fig. 3) with limited, but not negligible, consequences for several concessions (Perini et al., 2015; Trembanis et al., 2017).

The hydrodynamics of the regional domain are well described in terms of storm waves and surges (IDROSER, 1996; Ciavola et al., 2007). The area is micro-tidal (neap tidal range: $0.3-0.4 \mathrm{~m}$; spring tidal range: $0.8-0.9 \mathrm{~m}$ ); the surge component plays an important role (1-in-2-year storm surge: $0.61 \mathrm{~m}$ ) and is mainly generated from the SE (Scirocco) winds (according to the orientation of the Adriatic Sea). Furthermore, the wave climate is low energy (mean $\mathrm{Hs}-0.4 \mathrm{~m}$; $60 \%$ of waves are below $1 \mathrm{~m}$ ). However, extreme events can 


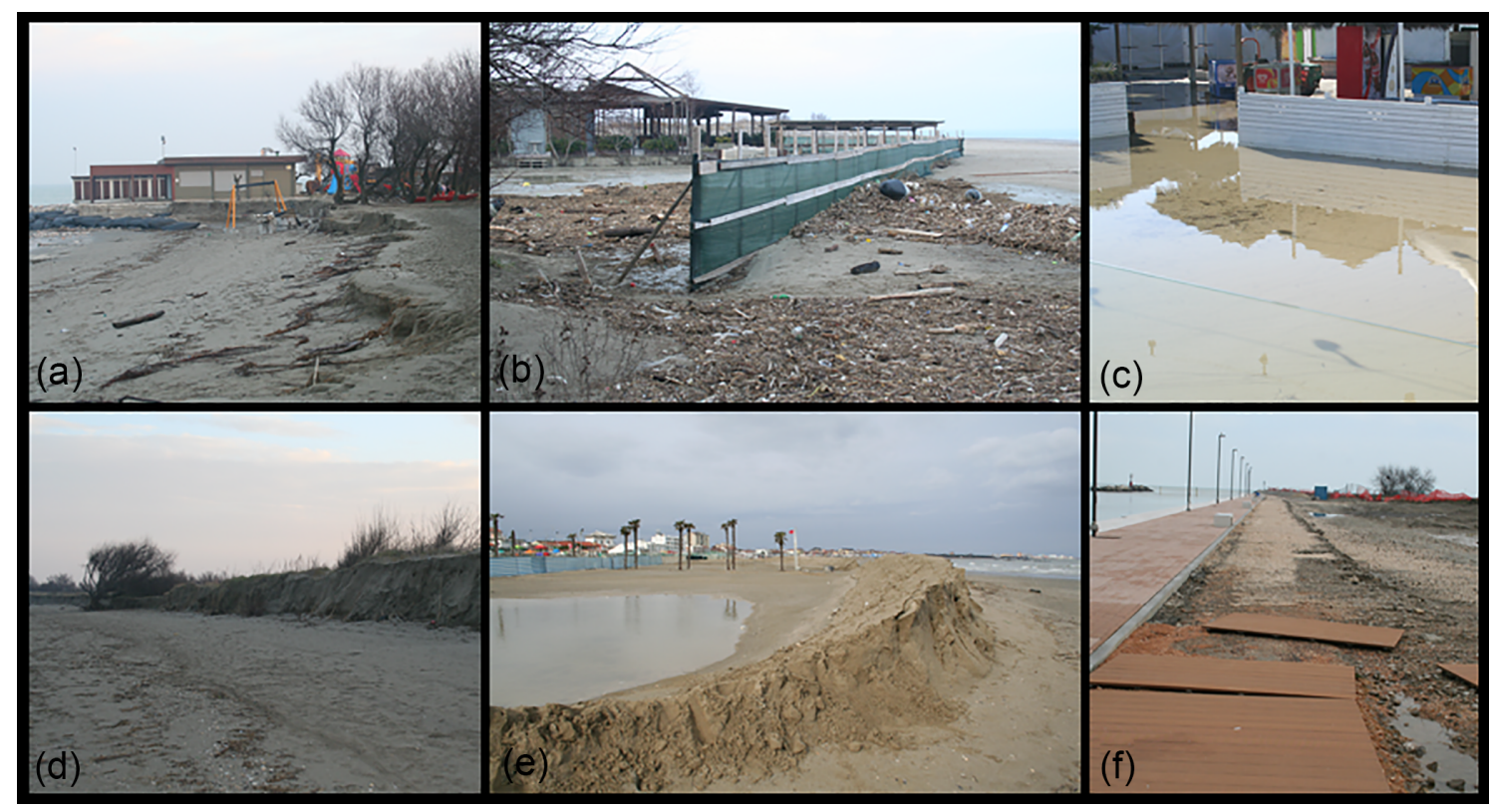

Figure 3. Impacts of the event in February 2015 on the Lido degli Estensi-Spina case study area. Impacts of erosion and flooding on concessions at Lido di Spina south (a, b) and Lido degli Estensi (c); sandy scarp due to the erosion of the dune in the south of Lido di Spina (d); eroded winter dune in Porto Garibaldi (e); damages to the Porto Canale front at the Lido degli Estensi (f).

be energetic, such as the storm of September 2004 (maximum $\mathrm{Hs}=5.65 \mathrm{~m}$, estimated by Ciavola et al., 2007) or the one of 5-6 February 2015 (maximum $\mathrm{Hs}=4.66 \mathrm{~m}$, measured at the Cesenatico buoy shown Fig. 1b1; Perini et al., 2015; Trembanis et al., 2017).

The combination of high waves and storm surges, whose combined probability of occurrence in the area was assessed by Masina et al. (2015), can have strong impacts at the regional level, as demonstrated by Armaroli et al. (2009), Armaroli et al. (2012) and Harley and Ciavola (2013). Notably, based on historical data (Perini et al., 2011), Armaroli et al. (2012) provided a set of critical storm thresholds for natural and urbanised beaches to characterise potentially impacting storms. The thresholds included a combination of offshore $\mathrm{Hs}$ and total water level (TWL): (1) $\mathrm{Hs} \geq 2 \mathrm{~m}$ and TWL (surge + tide) $\geq 0.7 \mathrm{~m}$ for urbanised zones and (2) $\mathrm{Hs} \geq 3.3$ and TWL (surge + tide) $\geq 0.8 \mathrm{~m}$ for natural areas with dunes.

\section{Methodology}

\subsection{General approach: from source to consequences}

The analysis framework employed in this study follows Jäger et al. (2018) and is based on the use of the SPRC model (FLOODsite, 2009; Oumeraci et al., 2015), as shown in Fig. 4. This model is widely used in coastal risk management (e.g. Narayan et al., 2014) and permits a clear representation of all risk components and their links from source to consequence.
The source includes the forces determining coastal response to the impact of extreme storms, which in this case are essentially a set of events representative of the storm climates of the study sites over the entire intensity range (from moderate to extreme). These storms propagate through the pathway, causing erosion at the coast and inundation on the hinterland. Both hazards are the main focus of the analysis. The pathway is solved through a process-oriented model chain to propagate storms and quantify induced processes. These are assessed for the entire coastal domain where receptors are present, characterised by their location and typology, which define their exposure and vulnerability to each hazard. Finally, consequences are evaluated by combining the vulnerability and exposure of each receptor with the magnitude of the hazards.

Since the main objective of the analysis is to test risk reduction strategies to help decision makers in future planning, the framework is applied under current conditions (CUS), which define the baseline scenario and climate change scenarios (CCSs) to define a plausible future projection. Finally, the analysis is repeated considering different risk reduction measures.

The BN approach reproduces the steps of the SPRC model through dependency relations between variables. This affects the application of the steps of the SPRC model, as explained in the following sections. At the same time, the BN data assimilation capabilities are used to integrate large amounts of simulations, i.e. results from multiple sources at multiple receptors. The BN integrates dependency relations between 


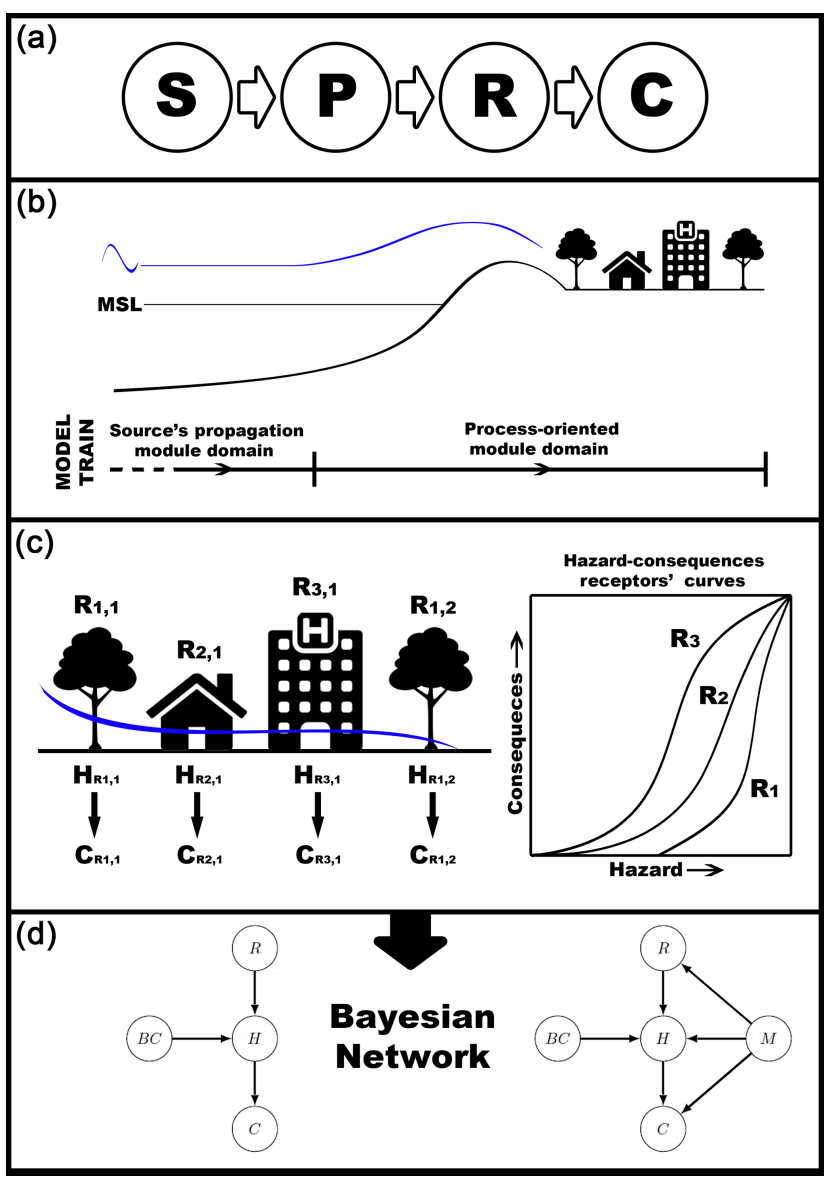

Figure 4. General methodology. (a) The SPRC conceptual framework is implemented through (b) a model chain, which consists of a propagation module of the source $(\mathrm{S})$ and a process-oriented module for the coastal area reproducing the pathway $(\mathrm{P})$. Then, $(\mathbf{c})$ the consequences $(\mathrm{C})$ are calculated based on the computed hazards $(\mathrm{H})$ at the receptor $(\mathrm{R})$ scale by using vulnerability relations (i.e. hazardconsequences functions). In the last step (d), all variables including source boundary conditions (BC) are fitted in a BN, as well as impacts and the implementation of measures $(\mathrm{M})$.

source, hazard, and consequences, at the receptor scale, for all available incoming conditions and scenarios.

\subsection{Source: identification and design}

To properly characterise storms, all relevant variables controlling the magnitude of induced hazards (erosion and inundation) must be considered, i.e. Hs, wave period (Tp), wave direction, storm duration, and water level. In this approach, source characteristics are defined in terms of a set of representative storms that cover the typical conditions at each study site. This information is obtained from existing wave time series or bulk data of the events (recorded or modelled), usually in deep waters, propagated towards the coast to characterise storm conditions at the nearshore of the study areas. Probable combinations that cannot be covered using exist- ing records are represented by synthetic design storms (e.g. Poelhekke et al., 2016; Plomaritis et al., 2018; Jäger et al., 2018). The storm events were selected based on the information available for each study site through the RISC-KIT WEB-GIS impact-oriented database (Ciavola et al., 2018; http://risckit.cloudapp.net/risckit/\#/), which provided storm characteristics and socioeconomic impacts of the events. In addition, time series of waves (either bulk $\mathrm{Hs}, \mathrm{Tp}$ and mean direction, or spectrum) and water levels during each storm event were used when this information was available. In order to be used in a BN approach, storm characteristic variables must be discretised in ranges which define the resolution of the source description. In this application, used simulations cover uniformly all variable combinations, assuming no prior knowledge of their statistics.

For the Tordera Delta case, the selected variables to define storm scenarios were $\mathrm{Hs}$ at the peak of the storm, total storm duration, and incoming storm direction. Tp does not significantly vary during storms in the study area (see Mendoza et al., 2011) and was not included as a characteristic variable. Due to the coastline configuration and morphology, the area is sensitive to the direction of the incoming storm (Sanuy and Jiménez, 2018). Thus, the main directions in terms of dominant (E) and secondary (S) storms needed to be considered separately. Finally, the position of the mean sea level (MSL) during the event was included to reproduce hypothetical future projections of sea level rise (SLR) due to climate change. The selected bins for each variable can be seen in Table 1 . These lead to 12 combinations defining the source under current MSL and 12 under future MSL (given by a SLR scenario). Each combination of states is represented by two simulations of slightly different storms to account for potential variability within variable ranges, leading to a total of 24 simulations under the current MSL and 24 under SLR. Of the 24 simulations under current MSL, 16 correspond to historic (recorded) events including the two largest, which occurred in November 2001 and December 2008. These were classified as extreme storms (category V) according to the Mendoza et al. (2011). To include the full range of cases, the remaining eight storms were completed by using combinations of Hs-duration-direction not previously recorded. These events were modelled assuming they follow a triangular-shaped evolution with the peak intensity at the half of their duration (see e.g. McCall et al., 2010; Poelhekke et al., 2016). Data used to reproduce the historic events include the time series of hindcast wind fields and 2-D wave spectra time series in deep waters for the NW Mediterranean (Guedes-Soares et al., 2002; Ratsimandresy et al., 2008). Wave conditions must propagate towards the coast to properly define storm events at the study site. At the Catalan coast, the storm surge contribution to the sea surface level is a magnitude lower than the wave-induced component, and the two variables are uncorrelated (Mendoza and Jiménez, 2008). All historical events with recorded associated water levels were simulated with the real storm surge, 
Table 1. Source characterisation. Variable discretisation applied at the study sites. NC denotes a variable not considered in a study case and therefore not divided in ranges.

\begin{tabular}{|c|c|c|c|c|c|}
\hline & Hs (m) & $\begin{array}{r}\text { Storm } \\
\text { duration }(\mathrm{h})\end{array}$ & $\begin{array}{r}\text { Incoming } \\
\text { direction }\left({ }^{\circ} \mathrm{N}\right)\end{array}$ & $\begin{array}{r}\text { TWL } \\
(\text { tide }+ \text { surge })(\mathrm{m})\end{array}$ & $\begin{array}{l}\text { Mean sea } \\
\text { level }\end{array}$ \\
\hline Tordera Delta & $\begin{array}{l}2-3 \\
3-4 \\
4-5\end{array}$ & $\begin{array}{r}6-30 \\
30-65\end{array}$ & $\begin{array}{r}30-135(\mathrm{E}) \\
135-220(\mathrm{~S})\end{array}$ & $\begin{array}{r}0-0.6 \mathrm{~m} \\
\mathrm{NC}\end{array}$ & $\begin{array}{l}\text { Current } \\
\text { Current }+0.73 \mathrm{~m} \\
\text { Morph. response included }\end{array}$ \\
\hline Lido Degli Estensi-Spina & $\begin{array}{l}2-3 \\
3-4 \\
4-5 \\
5-6\end{array}$ & $\begin{array}{r}12-68 \\
\mathrm{NC}\end{array}$ & $\begin{array}{r}60-135 \\
\mathrm{NC}\end{array}$ & $\begin{array}{l}0.65-1.05 \\
1.05-1.45 \\
1.45-1.85\end{array}$ & $\begin{array}{l}\text { Current } \\
\text { Current }+0.30 \mathrm{~m} \\
\text { No morph. response }\end{array}$ \\
\hline
\end{tabular}

while the synthetic storms were simulated with a storm surge of a $0.25 \mathrm{~m}$ constant throughout the event, as representative of the site according to the same authors.

Previous works in the area of the Lido degli Estensi-Spina case study have identified the dominant role of wave height and total water level in controlling the magnitude of storminduced erosion and inundation (Armaroli et al., 2009, 2012). Due to this, variables used to characterise the source were the maximum Hs and maximum TWL (surge + tide) during each storm event. Thus, wave period and the direction of the storms were not considered as a source characteristic variable to be discretised. The used range for each variable is shown in Table 1 . Seven historically based events were selected from the RISC-KIT Database, and to cover all 12 possible combinations in the CUS five additional synthetic events were considered. Notably, for several historic events, neither reliable nor continuous time series for waves and water levels were available from local measuring stations. To ensure consistency, both historical and synthetic events were represented based on the following methodology. Starting with the list of bulk information for each event (maximum Hs, $\mathrm{Tp}$, main direction of the storm, maximum TWL or duration when available), storms following triangular-shaped evolution (e.g. Carley and Cox, 2003; Corbella and Stretch, 2012) for $\mathrm{Hs}, \mathrm{Tp}$, and surge were created. The peak of the waves was assumed to occur at the same time as the maximum surge (calculated as the difference between the TWL and maximum astronomical predicted tide). When bulk parameters were missing, the following "worst case" assumptions were introduced: Tp at peak of $10 \mathrm{~s}$, wave direction orthogonal to the shoreline, and duration based on similarity with other storms. Each storm representing a Hs-TWL combination was simulated twice, with slightly different directions, to account for potential variability on source characteristics, leading to 24 simulations in the CUS. Additional 24 simulations were performed to cover the CCS.

\subsection{Pathways: modelling multi-hazard impacts}

To simulate the pathway and obtain hazards of interest, a model chain was designed and adapted for each site (Fig. 4b). Any model can be used within the model chain, and results will be as good as the model is accurate. The chain must be able to reproduce all hazards to be assessed (i.e. erosion and inundation). To do this, a detailed 2-D process-oriented model designed to simulate coastal storm-induced processes is used, the XBeach model, which is able to provide integrated information on inundation and erosion (see Roelvink et al., 2009, for model details). At present it is a state-of-art model on coastal systems. However, the proposed framework can work with different (simpler) models when they are able to simulate the target processes (inundation and erosion). The XBeach model was used in both study cases.

The model chain for the Tordera Delta consists of two blocks, one "external" and one "internal". The external module comprises three models (HAMSOM, HIRLAM, and WAM) that supply the forcing conditions (time series of water levels, wind fields, and waves) and are run by Puertos del Estado (Spanish Ministry of Public Works). The output of these models is taken directly as an input for the internal module, which comprises the SWAN (Booij et al., 1996) and XBeach (Roelvink et al., 2009) models. SWAN was used to propagate wave conditions from deep waters to the offshore boundary of the XBeach model (20 m depth), while XBeach was employed to assess the extension and magnitude of inundation and erosion at the study site (local scale). The model chain was validated through the St. Esteve event in 2008, obtaining a Brier skill score of 0.68 for the morphological response of the emerged part of the beach (Sanuy and Jiménez, 2018). Simulation results can be considered excellent for scores over 0.6 (Sutherland et al., 2004)

The model chain for Lido degli Estensi-Spina only included the XBeach model. This simple approach was possible based on the assumption that the information derived from the RISC-KIT Database can be considered representative of the storm in the domain, as collected from different sources (e.g. offshore buoys, harbours' tide gauges, newspa- 
pers) along the Emilia-Romagna coast (Perini et al., 2011; Ciavola et al., 2018). The model was qualitatively validated using observed inundation extension and profile beach response of the February 2015 event (Perini et al., 2015; Trembanis et al., 2017).

\subsection{Receptors and consequences}

The methodology applied in this work individually identified receptors located at the study sites (Fig. 4c) (Jäger et al., 2017). First, receptors with homogeneous vulnerability characteristics were defined and separately considered. Then, for each group of receptors, polygons were drawn using a GISbased tool to account for their exact location and size. Finally, the polygons were intersected with the cells of the 2-D detailed model grid (XBeach) to assign to each receptor the nodes of the model that will affect it.

For the inundation hazard, the value of the maximum water depth inside each polygon (receptor) was used as the impact variable. Then, by using flood-damage curves for the corresponding receptor typology, inundation water depth was translated to relative damage. This was then translated into four levels of impact - none, low, medium, and high - which are dependent on the case and receptor (see the following sections). The chosen damage curves do not include uncertainties, and they are used as recommended by the Administration at each study site. This implies that damage ranges and damage-hazard relations are different and, therefore, final impact levels (from none to high) are specific to the site. This assumption aimed to better communicate results to local stakeholders.

The magnitude of the risk associated with erosion depends on the combination of vertical erosion and distance of erosion to the receptors. This was implemented by building multiple buffers (increasing in distance) around each receptor and applying the polygon intersection formerly explained with the gridded maximum vertical erosion output from XBeach. The definition of risk categories related to erosion thresholds and distances is also site dependent, given their different morphologies.

\subsubsection{Exposure and vulnerability in the Tordera Delta case study}

The distribution of receptors for the Tordera Delta case study was derived from cartographic information of the Catalan Cartographic Institute and completed manually through orthophoto analysis. The study site was divided into eight areas, of which four are located at the south of the river mouth, corresponding to the Malgrat de Mar municipality, and the other four to the north, corresponding to the Blanes municipality. These two sets of four areas were selected to enable the analysis of the impact at different bands regarding their distance to the limit of the public beach. The first band corresponds to the first $20 \mathrm{~m}$ of hinterland. The second band is
$30 \mathrm{~m}$ wide and located just after the first one, i.e. 20 to $50 \mathrm{~m}$ from the boundary of the public domain. The third covers the range from 50 to $75 \mathrm{~m}$, while the fourth band covers all the hinterland omitted between the end of the third band and the inland domain boundary. This enables an assessment of the distribution of the impacts in terms of distance to the coastline and allowed exploring setbacks as risk reduction measures. Three groups of receptors were identified to be homogeneous in terms of vulnerability, namely houses (concrete buildings), campsite elements (soft buildings and caravans), and infrastructure (promenade and road at the back of the beach). Table 2 shows the distribution of campsite elements and houses in the different areas. The infrastructural receptors (promenade at the north and road at the south) are only located in the first $20 \mathrm{~m}$ band (areas 1 and 5).

The consequences of flooding were assessed through flood-damage curves used to characterise the relative damage based only on water depth (Table 3). Data were obtained from the Agència Catalana de l'Aigua (2014).

The relative damage values to buildings and campsite elements were converted into the level of risk as follows: (i) no impact for $0 \%$ relative damage to buildings and campsite elements; (ii) low impact for damages below $26 \%$ to buildings and $50 \%$ for campsite elements; (iii) medium impact when damages to buildings range from 26 to $45 \%$ and damages to campsite elements range between 50 and $70 \%$; and (iv) high impact for relative damages higher than those formerly exposed for both receptors.

The buffers defined to assess the erosion hazard at the Tordera Delta are as follows: (i) a $20 \mathrm{~m}$ distance was used as a threshold from "none" to "low" erosion risk and corresponds to the average beach retreat at the site for a storm with a return period of 38 years (commonly used for infrastructural receptors similar to those in the Tordera Delta for a lifetime of about 25 years). (ii) The $12 \mathrm{~m}$ buffer (average retreat for the 10-year return period) was used as the threshold from low to "medium" impact. Medium impact is a postmonitoring situation where receptors will be exposed to the direct impact for relatively frequent storms. (iii) Finally, the $3 \mathrm{~m}$ buffer was used as the threshold for "high" impact risk, meaning that the receptor is directly affected by erosion at the toe or impacted by waves during the storm. A buffer was considered to be affected when vertical erosion was higher than $50 \mathrm{~cm}$.

\subsubsection{Exposure and vulnerability in the Lido degli Estensi-Spina case study}

The analysed receptors belong to the central area of the model domain at approximately $600 \mathrm{~m}$ from the lateral boundaries (Fig. 1b2). Two main types of receptors were selected: (i) the residential and commercial buildings mainly present in the towns of Lido degli Estensi and Lido di Spina and (ii) beach concessions on the beach directly facing the sea. In this study, only receptors belonging to the seafront of 
Table 2. Distribution of receptors at the Tordera Delta study site.

\begin{tabular}{lrr}
\hline Area & No. of houses & No. of campsite elements \\
\hline Area 1 (0-20 m, Malgrat de Mar) & 16 & 45 \\
Area 2 (20-50 m, Malgrat de Mar) & 10 & 71 \\
Area 3 (50-75 m, Malgrat de Mar) & 8 & 169 \\
Area 4 (>75 m, Malgrat de Mar) & 46 & 509 \\
Area 5 (0-20 m, Blanes) & 1 & 95 \\
Area 6 (20-50 m, Blanes) & 4 & 156 \\
Area 7 (50-75 m, Blanes) & 7 & 72 \\
Area 8 (>75 m, Blanes) & 51 & 189 \\
\hline Total & 143 & 1306 \\
\hline
\end{tabular}

Table 3. Vulnerability relations for houses and campsite elements at the Tordera Delta study site with and without flood resilience measures (FRM).

\begin{tabular}{lrrrr}
\hline & \multicolumn{4}{c}{ Relative damage (\%) } \\
\cline { 2 - 5 } $\begin{array}{l}\text { Water depth at the } \\
\text { receptor }(\mathrm{m})\end{array}$ & Houses & Campsites & $\begin{array}{r}\text { Houses } \\
\text { - FRM }\end{array}$ & $\begin{array}{r}\text { Campsites } \\
\text { - FRM }\end{array}$ \\
\hline 0 & & 0 & 0 & 0 \\
$0-0.3$ & 18.3 & 50 & 0 & 0 \\
$0.3-0.6$ & 26.5 & 71 & 18.3 & 50 \\
$0.6-0.9$ & 33.2 & 82 & 18.3 & 50 \\
$0.9-1.5$ & 44.7 & 89 & 26.5 & 71 \\
$1.5-2.1$ & 54.1 & 91 & 33.2 & 82 \\
$2.1-3.0$ & 64.5 & 100 & 44.7 & 89 \\
$3.0-4.0$ & 71.2 & 100 & 54.1 & 91 \\
$4.0-5.0$ & 75 & 100 & 64.5 & 100 \\
\hline
\end{tabular}

Table 4. Distribution of the receptors at Lido degli Estensi and Lido di Spina.

\begin{tabular}{lrr}
\hline Area & $\begin{array}{r}\text { Residential and } \\
\text { commercial } \\
\text { buildings }\end{array}$ & Concessions \\
\hline Lido degli Estensi seafront & 26 & 16 \\
Lido di Spina seafront & 47 & 28 \\
\hline
\end{tabular}

Lido degli Estensi and Lido di Spina were considered, as they are mainly impacted by sea storms. Receptors were extracted from a recent regional topographic map (Carta Topografica Regionale, scale $1: 25000$, year 2013). Table 4 summarises the identified receptors.

The vulnerability relation for inundation hazards was defined considering a flood-damage curve from a recent study on Italian territory by Scorzini and Frank (2015). This work was based on a micro- and macro-scale study of the impacts of the 2010 river flood in Veneto (Italy) on residential houses. In the current work, it was adapted and applied to the receptors of the area (see details in Table 5a) and relates the relative damage factor (values: $0-1$ ) to flood depth. In partic-
Table 5. Vulnerability relation for flooding adopted for the receptors at Lido degli Estensi-Spina without (a) and with flood resilience measures (b).

\begin{tabular}{lrr}
\hline & \multicolumn{2}{c}{ Flood relative damage factor $(-)$} \\
\cline { 2 - 3 } Flood depth $(\mathrm{m})$ & $\begin{array}{r}\text { (a) Adapted from } \\
\text { Scorzini and } \\
\text { Frank (2015) }\end{array}$ & $\begin{array}{r}\text { (b) Modified } \\
\text { considering } \\
\text { the FRM }\end{array}$ \\
\hline 0 & 0 & 0 \\
$<0.3$ & $<0.1$ & $<0.1$ \\
$0.3-0.7$ & $0.1-0.2$ & $<0.1$ \\
$0.7-1.1$ & $0.2-0.3$ & $0.2-0.3$ \\
$>1.1$ & $>0.3$ & $>0.3$ \\
\hline
\end{tabular}

ular, the worst case curve was used, which represents floodrelated damages to single-family detached buildings with a basement. Although this curve is for residential buildings, it was assumed the same for commercial buildings and beach concessions, as no additional and specific information was available. The curve was modified considering the risk reduction implementation described in Sect. 3.5.2. The level of flood risk was defined as follows: none, when the relative damage is null; low, when the relative damage factor is higher than zero but lower than 0.1 ; medium, for a factor between 0.1 and 0.2 ; and high, for a relative damage factor higher than 0.2 .

The vulnerability relation for erosion was defined for concessions only. The impacts due to the erosion hazard were defined based on a two-buffer approach for each receptor: the first buffer was the receptor limits in the ground, and the second included a corridor of $10 \mathrm{~m}$ around the receptor.

Erosion was considered present if $>0.05 \mathrm{~m}$ (vertical) and significant when $>0.5 \mathrm{~m}$. The erosion risk categories for each receptor were set as follows: (i) safe, when there is no erosion in any buffer; (ii) potential damage, when erosion is present in the $10 \mathrm{~m}$ buffer and/or present but not significant in the receptor itself; and (iii) damage, when the erosion limit of $0.5 \mathrm{~m}$ is exceeded within the receptor limits. Notably, the threshold of $0.5 \mathrm{~m}$ was set by considering the uncertainty of 
the model grid topography $( \pm 0.15 \mathrm{~m})$ and assuming that the foundations of the concessions are a minimum of $0.2 \mathrm{~m}$ thick.

\subsection{Testing scenarios and risk reduction alternatives}

To compute the analysis under CCSs and under the implementation of risk reduction measures, it was necessary to identify the variables and settings affected by each scenario, either a future projection or implementation of a measure. Therefore, an appropriate approach was selected to consider these modifications in the methodology chain.

The CCSs mainly affect the hazard and, therefore, are applied in the modelling chain. The risk reduction measures can affect both hazard and vulnerability/exposure variables. In the following, the implementation of the CCSs and measures is described for each case study, emphasising the affected variables and steps of the methodology. The measures were pre-selected considering interviews with stakeholders and were assumed to be fully implemented and completely effective (measure uptake and effectiveness: 100\%) in all cases.

\subsubsection{Climate change scenarios in the case studies}

Future projections of MSL were based on the AR5 RCP8.5 (Church et al., 2013). Other factors such as changes in storminess, wind speed, or wave height were not expected to change significantly in the NW Mediterranean (Lionello et al., 2008; Conte and Lionello, 2013) and are characterised by high uncertainty in the Northern Adriatic (IPCC, 2013). Data to include the SLR in the assessment of future scenarios were provided by the EC Joint Research Centre database (for further detail, see Vousdoukas et al., 2016). For the Tordera Delta study case, the time horizon of 2100 was chosen, while the 2050 projection was used for Lido degli Estensi-Spina, because the projections in the Adriatic are more uncertain than in the NW Mediterranean. Therefore, the 2100 horizon could yield highly unreliable results.

At the Tordera Delta, the RCP8.5 estimates an increase of $0.73 \mathrm{~m}$ by 2100 . Therefore, all 24 simulations described in Sect. 3.2 were repeated with the projected future sea level. Moreover, the potential beach accommodation to SLR was modelled following Bosom (2014) and Jiménez et al. (2017). This was accomplished assuming an equilibrium coastal profile response following the Bruun rule (Bruun, 1962), resulting in landward and upward displacement of the beach profile. Dunes preserve the pre-SLR shape when there is enough accommodation space, otherwise the shape is cut. The estimated shoreline retreat due to the SLR in the area is $22 \mathrm{~m}$. Thus, morphological response to SLR is included in the assessment. Finally, Casas-Prat and Sierra (2012) predicted a directional change in mean sea conditions from the current dominant (E) to the secondary direction (S). This effect was explored by assessing only eastern incoming storms in present conditions and imposing an equal frequency of

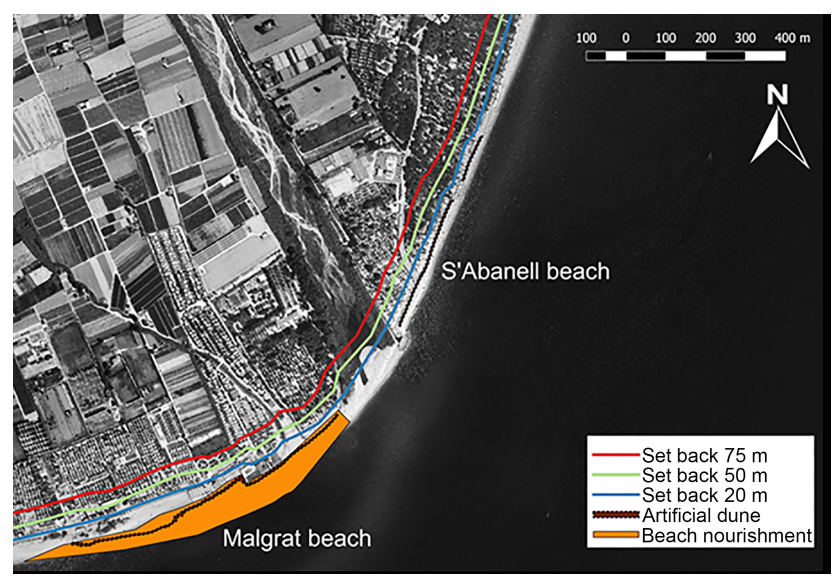

Figure 5. Risk reduction measures at Tordera Delta: receptor setbacks $(20,50$, and $75 \mathrm{~m})$ and nourishment + dune (beach nourishment at Malgrat beach + artificial dune at S'Abanell and Malgrat beaches).

eastern and southern incoming storms in future projections. Therefore, three different CCSs were explored: (i) CCS1 is CUS + SLR with the corresponding estimated beach accommodation; (ii) CCS2 is CUS + effect of direction switch of incoming storms, and (iii) CCS3 is the assessment of the contribution of both components if occurring at the same time.

In Lido degli Estensi-Spina, the combined contribution of the predicted SLR with the subsidence component (not negligible in the area; e.g. Taramelli et al., 2015) was implemented. The resulting value of relative SLR by 2050 used in the analysis is $0.30 \mathrm{~m}$. The position of the MSL was changed for all forcing events, adding the predicted relative SLR by 2050 in the CCS. The morphological accommodation to the SLR was not implemented in the numerical analysis; however, the implication of this choice is discussed in Sect. 5.2. In total, 24 additional simulations were run for the CCS.

\subsubsection{Risk reduction alternatives in the case studies}

Three risk reduction measures were tested for the Tordera Delta zone (see Fig. 5): (i) receptor setback, (ii) flood resilience measures, and (iii) nourishment + dune.

The receptor setback measure affects the exposure of the receptors. It entails removing all receptors inside a defined band measured from the public domain coastal limit (the limit between the back of the beach and hinterland). Three scenarios of the setback were simulated: 20,50 , and $75 \mathrm{~m}$.

The flood resilience measures affect the vulnerability of receptors so that for a given water depth, the expected impact decreases when the measure is implemented. It was assumed that resilience measures such as raised electricity outlets and utilities, adapted flooring, resilient plaster, and waterproof doors and windows were installed in all houses and campsite elements. This measure was implemented by assuming a modified damage curve as shown in Table 4. 


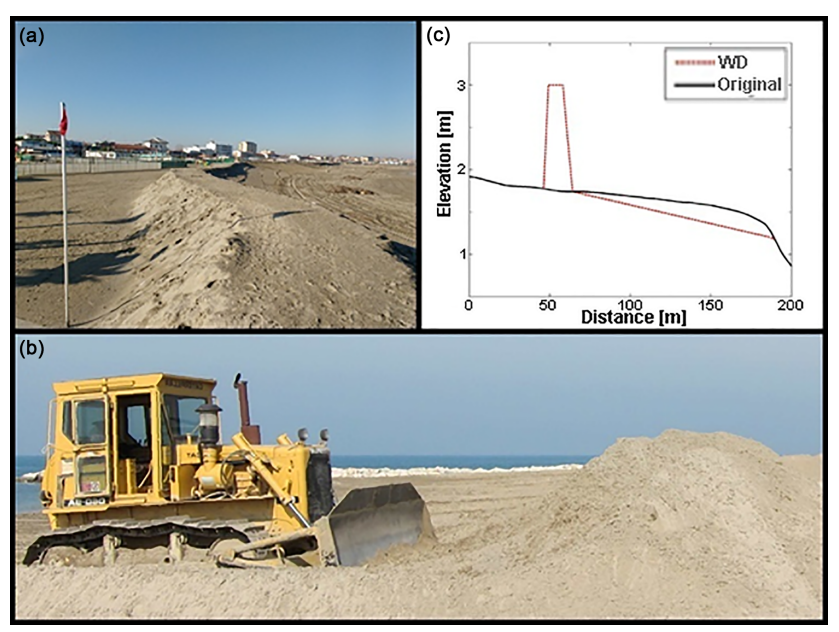

Figure 6. Artificial winter dunes in Emilia-Romagna: (a) winter dune in Porto Garibaldi (Comacchio, Italy); (b) building of a winter dune by beach scraping at Lido di Dante (Ravenna, Italy) (Harley, 2014); (c) representative model profiles at Lido di Spina north (original: black solid line; with winter dune measure: red dashed line).

Finally, the nourishment + dune changes the pathway and affects the inundation/erosion hazard. It includes beach nourishment at the south of the river mouth to increase the beach width by $50 \mathrm{~m}$ over $1 \mathrm{~km}$, where the highest erosion occurs. In addition, the level at the top of the beach was increased on both sides of the river mouth, with non-erodible sandbags at the northern side, where the campsites are closer to the coastline, and a sandy dune at the southern side. At both sides, the final height of the protective measure was $+4.8 \mathrm{~m}$ a.m.s.l. Since this measure affects the pathway, it had to be implemented in the XBeach grid. Thus the 48 storms (24 current MSL, 24 current MSL + SLR) were simulated again with the edited morphology arriving to the final 96 simulations.

The selected measures tested for the Lido degli EstensiSpina case study were (i) a winter dune system, affecting both flooding and erosion impacts, and therefore the hazards modelling process and (ii) flood resilience measures, influencing the flood vulnerability relations of receptors.

The winter dune (see Fig. 6) is a common risk reduction practice along the Emilia-Romagna coast, especially in the Ravenna province (Harley and Ciavola, 2013), and regularly implemented by local concessionaires without a scientifically based design criterion. It consists of a set of embankments built on the beach in front of concessions through beach scraping or sand replenishment (less frequent option). This risk reduction measure was implemented in the XBeach model. The winter dune was designed as a continuous dune that protects more than one concession, introducing breaks in the continuity of the feature where natural or human obstacles or passages were located. The top of the dune was fixed at $3 \mathrm{~m}$ a.m.s.l. and the width (at the top) at $10 \mathrm{~m}$. The dune was integrated in the model modifying the bed levels through

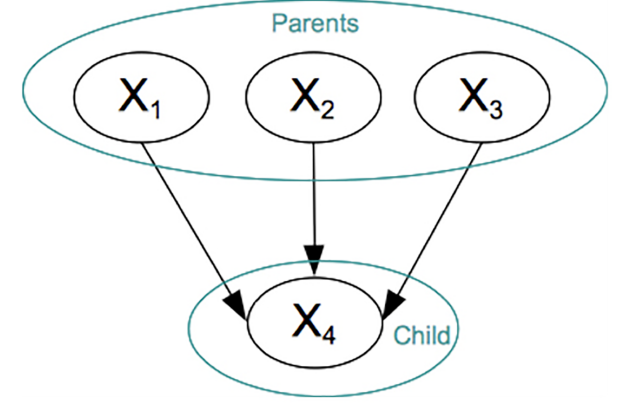

Figure 7. BN graph with four nodes.

the DuneMaker 2.0 tool (Harley, 2014). Both the CUS and CCS were tested with this measure adding 48 additional simulations.

The flood resilience measures decrease the receptor's physical vulnerability to floods. It was assumed that the effective application of these measures would decrease the damages for water levels lower than a certain threshold, assumed here as $0.7 \mathrm{~m}$ (e.g. all electronics must be placed above the threshold). This assumption was integrated in the analysis by modifying the selected depth-damage curve, as defined in Table 5b, and included in the BN. Considering the adopted definition of flood risk levels (see Sect. 3.4.2), the measure results in a complete obliteration of receptors for the medium flood risk, therefore increasing the receptors at the low level and not affecting receptors at high risk.

\subsection{Bayesian-based decision network.}

BNs use probability theory to describe the relationships between many variables and can evaluate how the evidence of some variables influence other unobserved variables. For example, evidence could be a forecast of the source variables characterising an impending storm. In contrast, local hazards and damages in the coastal area have not yet been observed, but can be predicted with the BN. The model can also be updated with artificial evidence to explore extreme event scenarios or investigate the potential of risk reduction plans.

A BN is based on a graph (Fig. 7). It consists of nodes connected by arcs that represent random variables and the potential influences between them. The direction of the arcs is crucial for the probabilistic reasoning algorithm of the $\mathrm{BN}$, but does not necessarily indicate causality. For any two variables connected by an arc, the influencing one is called a parent, while the one influenced is referred to as the child. Thus, in Fig. $7, X_{1}, X_{2}$, and $X_{3}$ are the parents of $X_{4}$. A simple way to parameterise a $\mathrm{BN}$ is to discretise continuous variables after defining their data range and to specify conditional probability tables for each node. The authors adopted this approach. The conditional probability tables indicate how much a variable could be influenced by others. Mathematically, the graph structure and conditional probability tables define the joint 
distribution of all variables in the network, $\mathrm{X}_{1}, \ldots, \mathrm{X}_{n}$, based on the factorisation of conditional probability distributions (Eq. 1):

$p\left(\mathrm{X}_{1}, \ldots, \mathrm{X}_{n}\right)=\prod_{i=1}^{n} p\left(\mathrm{X}_{i} \mid \mathrm{pa}\left(\mathrm{X}_{i}\right)\right)$,

where $\mathrm{pa}\left(\mathrm{X}_{i}\right)$ are the parents of node $\mathrm{X}_{i}$ (Pearl, 1988; Jensen, 1996). Once the joint distribution has been defined, the effects of any evidence can be propagated with efficient algorithms throughout the network (Lauritzen and Spiegelhalter, 1988).

In the RISC-KIT project, a generic structure for a $\mathrm{BN}$ based approach that can support decision-making in coastal risk management was proposed. This structure is based on the SPRC and has five components (node types): source boundary condition, hazard, receptor, impact/consequence, and risk reduction measure. Typically, each component includes several variables. Figure $4 d$ shows their influence on each other. In general, all boundary conditions influence all hazards. Each type of receptor (e.g. people, buildings, infrastructure, and ecosystems) is represented by a node where different areas are the different bins (proxy for the locations of receptors on the site). Hazard intensity is conditioned by the location of the receptors and the presence of measures. Consequences are conditioned by hazard intensity, receptor type and presence of measures.

Alongside the generic structure, a $\mathrm{C}++$ programme that automatically creates the BN (https://github.com/openearth/ coastal-dss, last access: May 2018) is also provided. As input, the programme requires variable definitions and landuse data, vulnerability relationships, and a 2-D gridded simulation output of numerical physical process-based models of hindcast or synthetic extreme event scenarios. Essentially, the programme extracts the values of hazard variables from the simulation output at the locations of every individual receptor so that hazard distributions for each receptor type can be obtained. Because each simulation contains the coastal response to one storm scenario under a specific set of measures, the distributions are conditional and can be stored directly as entries of the conditional probability tables associated with each hazard node. Being parents of the hazard nodes, boundary conditions, receptors' areas, and risk reduction measures define the dimensions of the conditional probability tables. In the final step, the conditional hazard distributions were transformed to conditional impact distributions with vulnerability steps. In the present application, the BN-based approach is applied assuming no prior knowledge on the statistics of the source. Thus, all source variable combinations are equally fed into the BN resulting as uniform distributions of either Hs, duration, TWL, or direction. Each combination is represented by two simulations of slightly different storms to include some uncertainty due to intra-bin variability. No other uncertainty is included. Therefore, the present application is deterministic, a Bayesian-based decision network which mainly uses the data assimilation capacity of the BN as principle advantage with respect to other methodologies (e.g. GIS-based assessments). Additionally, the BDN allows also reverse assessments, where output variables (i.e. consequences) can be constrained to get conditioned results on the source variables. In the Discussion section further guidance into a fully probabilistic $\mathrm{BN}$ approach integrating multiple sources of uncertainty is presented.

\subsubsection{BDN implementation at the case study sites}

The schemes of the BDNs implemented for the Tordera Delta and Lido degli Estensi-Spina case study sites are shown in Figs. 8 and 9, respectively. The nodes (circles) define the variables of the network, while arcs (arrows) show the relations between the variables. The boundary conditions (blue), and the location and distributions of the receptors (grey) affect the hazards' nodes (dark orange). The hazard is then transformed through the vulnerability relations into consequences (light orange). The measures' nodes (green) can affect different node types depending on the effect (by definition) of the measure. The structure is very flexible and can be applied at different coastal settings. The scheme can be adapted with different boundary conditions, hazards, receptors, consequences, and measures, depending on the needs driven by research and/or coastal management objectives. It follows that, for very similar coasts, or even for the same case study, the scheme can differ. The variables and bin ranges characterising boundary conditions are pre-selected by the user. Bins are equidistant and covering the observed values at each study site (Table 1). Additional non-observed ranges are introduced to account for SLR. The used number of intervals is a compromise between accuracy and computational effort. A total number of 96 model runs were required for the applied setup at each case study site. As a reference, using parallel simulations with 48 threads, the ratio computation time over real storm time was $\sim 0.2$, meaning that a $40 \mathrm{~h}$ storm takes $\sim 8 \mathrm{~h}$ of simulation time.

\section{Results}

The results of scenario testing are provided for each case study through an integrated comparison of percentages of receptors at each level of flooding and erosion risks. This is done by comparing the risk levels under current and CCSs, with and without measures. The results of the scenarios that will be presented in the following sections are produced by integrating in subsets all 96 simulations at each study site.

Figure 10 shows an example of the integration of simulations at the Tordera Delta considering the CUS without measures. The figure includes three boxes with different level of (un)constrained boundary conditions and corresponding results in terms of erosion risk to infrastructures. In box A, both Hs and storm duration are constrained to a specific bin (in 


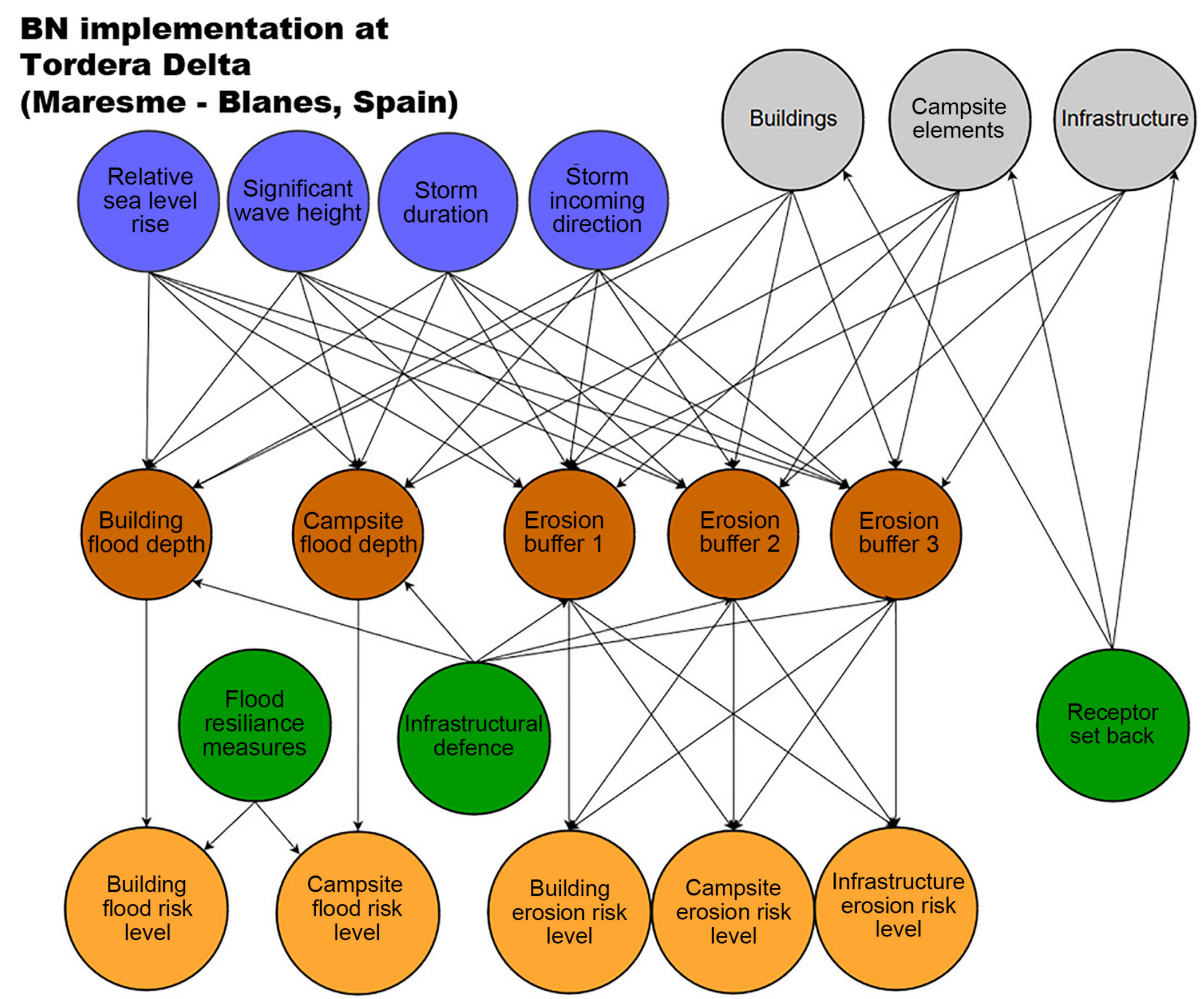

Figure 8. Bayesian network scheme for the Tordera Delta site.

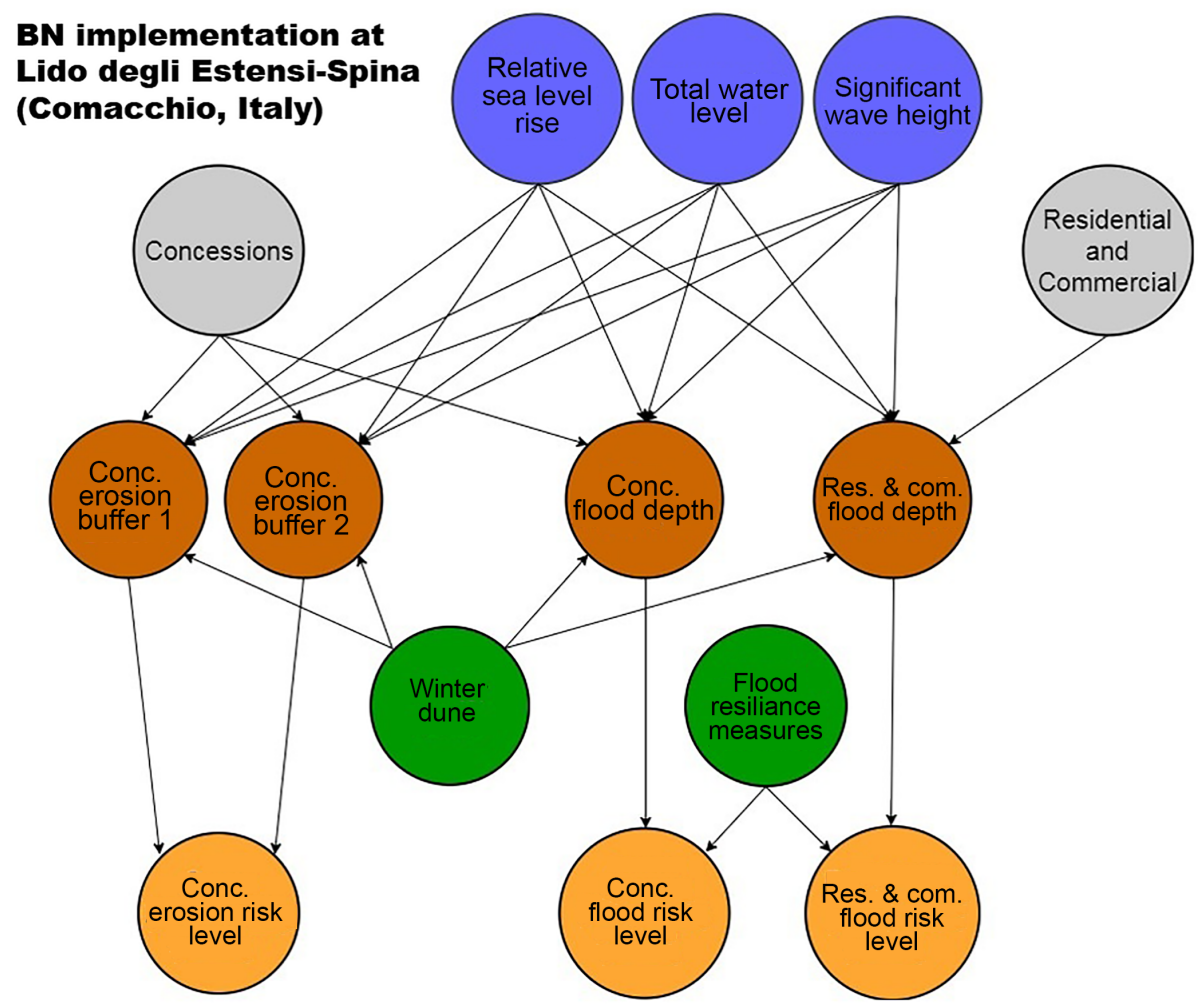

Figure 9. Bayesian network scheme for the Lido degli Estensi-Spina site. 


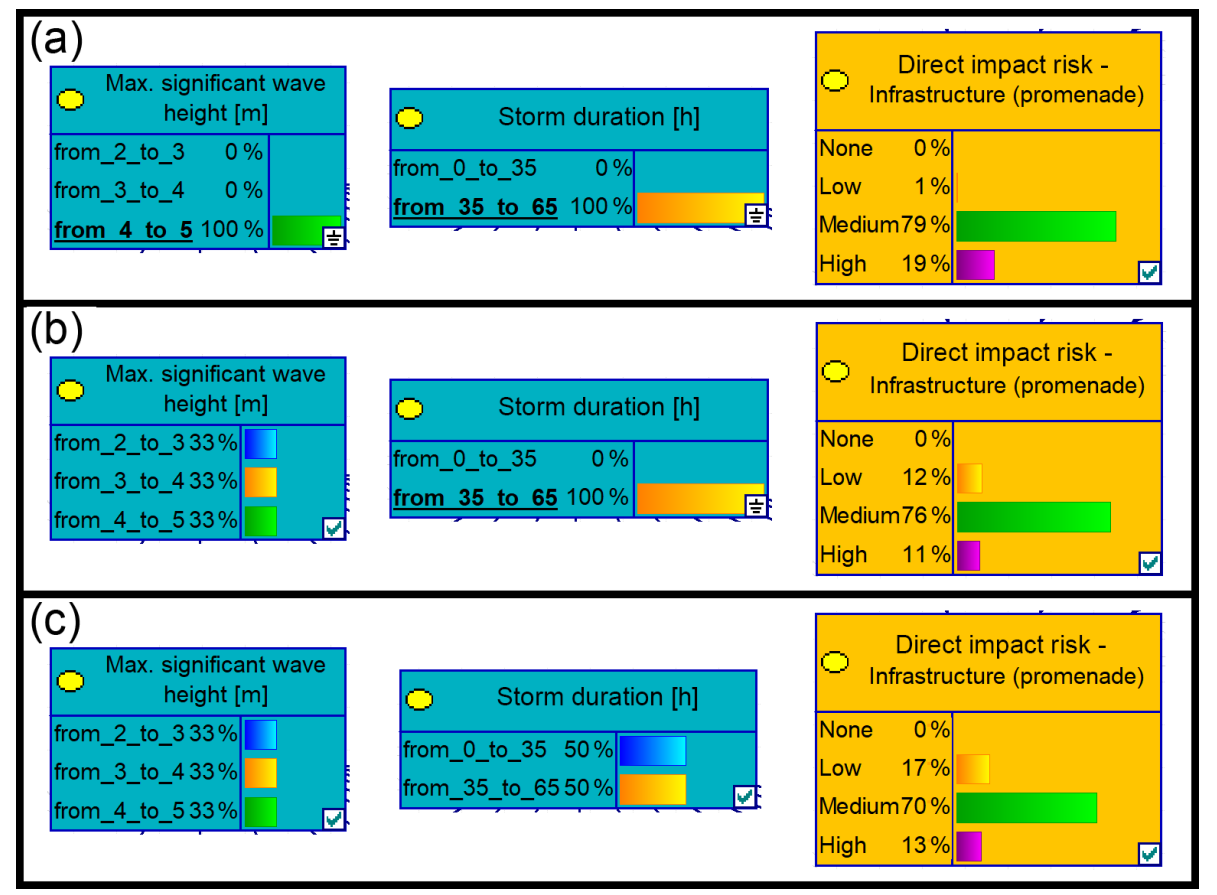

Figure 10. Example of result integration in the Bayesian-based decision network. Combinations of Hs and duration to obtain erosion risk at infrastructures in Tordera Delta. Total water level is constrained to "current" and direction to eastern incoming storms.

this case given by the highest values) and thus, results of two different simulations are integrated to obtain the final output. In box B, Hs is unconstrained while duration is constrained to the highest bin. In this case, the final result is produced by integrating six simulations (two per each Hs bin). Finally, in box $\mathrm{C}$, both Hs and duration are unconstrained and the output is given by integrating 12 simulations ( 2 per each $\mathrm{Hs}$ and duration bin combination), which represent the overall dataset for CUS without measures for Tordera Delta.

The current BDNs have been fed assuming no prior knowledge on the boundary conditions' distributions (i.e. any boundary condition is uniform when unconstrained). This approach is adequate to explore scenarios and to assess the efficiency of protection measures in terms of impact reduction.

\subsection{Tordera Delta}

The result assessment was performed separately for both sides of the river at S'Abanell beach at the north and Malgrat beach at the south. The inundation impact assessment considered all receptors at the study site whereas the erosion analysis focused only on the first $20 \mathrm{~m}$ band of hinterland because the only receptors exposed to an erosion hazard are located in that area.

The results of the flooding impacts, here presented for campsite elements, indicate that under current conditions, receptors at both sides of the river mouth are expected to suffer the same magnitude of damages: $80-83 \%$ of elements will be safe, while only $2-3 \%$ of the elements are under highimpact risk (Fig. 11).

Under CCSs, a different behaviour at each side of the river mouth is detected. Southwards of the river mouth, the beach is highly sensitive to changes in both storm direction and SLR (Figs. 11 and 12). Thus, when CCS3 conditions are analysed in Malgrat, the BDN indicates that $69 \%$ of campsite elements are affected, with $41 \%$ being at high risk. In contrast, the beach at the north (S'Abanell) is highly sensitive to SLR (CCS1, Fig. 11) but it is not affected by a potential change in storm direction (CCS2 and CCS3, Fig. 12).

Comparing the effectiveness of the risk reduction measures highlights nourishment + dune as the most effective one against flooding under current and climate change scenarios. As expected, the effectiveness is higher in Malgrat than in S' Abanell, as beach nourishment is located only south of the river mouth whereas the dune is present on both sides. It was observed that all significant impacts (medium and high) to receptors under current scenario were removed for both sides of the river. Moreover, at Malgrat, the number of affected receptors was reduced by $\sim 20 \%$ for the CUS, CCS1, and CCS2 scenarios and $\sim 40 \%$ under CCS3.

The implementation of the flood resilience measures was effective in terms of preventing high impacts on any receptor, but did not significantly reduce the total number of receptors affected by some level of risk. The magnitude of reduction of receptors at risk was $\sim 9 \%$. It should be mentioned that this is a theoretical measure, as we assumed that it is properly designed, implemented, and $100 \%$ effective for site conditions. 

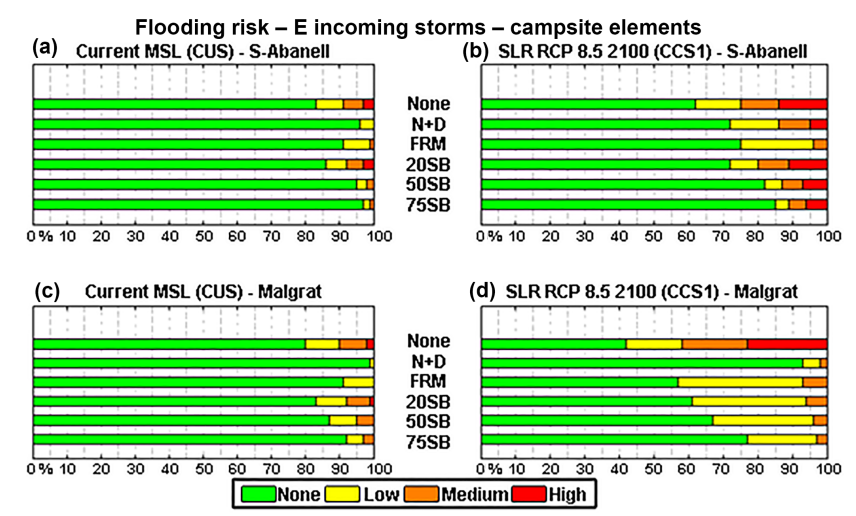

Figure 11. Distribution of campsite elements at every level of flooding risk: (a) current scenario at S'Abanell; (b) climate change scenario 1 (SLR) at S'Abanell; (c) current scenario at Malgrat; (d) climate change scenario 1 (SLR) at Malgrat. Each bar in a panel represents a risk reduction configuration ("none": no measure implemented; "N + D": nourishment and dune; "FRM": flood resilience measures; “20SB, 50SB, and 75SB": 20, 50, and 75 m setbacks, respectively).
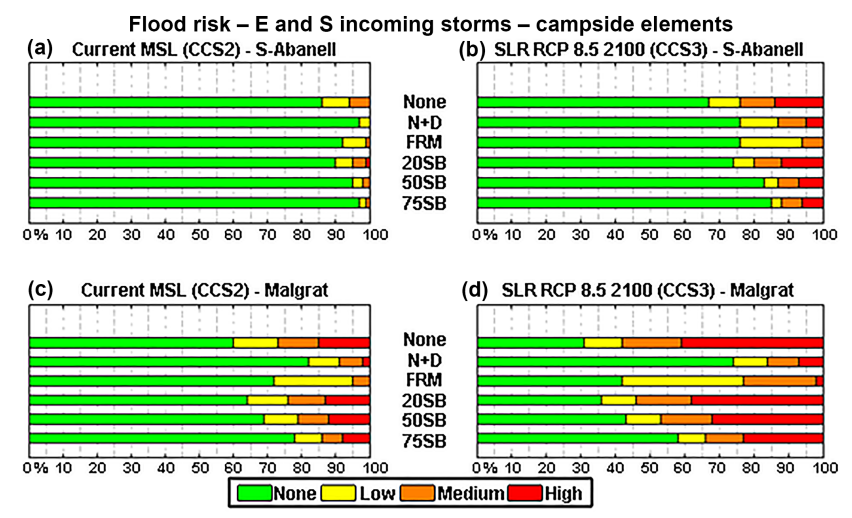

Figure 12. Distribution of campsite elements at every level of flooding risk: (a) climate change scenario 2 (incoming storms from $\mathrm{E}$ and S) at S'Abanell; (b) climate change scenario 3 (incoming storms from $\mathrm{E}$ and S + SLR) at S'Abanell; (c) climate change scenario 2 (incoming storms from $\mathrm{E}$ and $\mathrm{S}$ ) at Malgrat; (c) climate change scenario 3 (incoming storms from $\mathrm{E}$ and $\mathrm{S}+\mathrm{SLR}$ ) at Malgrat. Each bar in a panel represents a risk reduction configuration ("none": no measure implemented; "N+D": nourishment and dune; "FRM": flood resilience measures; "20SB, 50SB, and 75SB": 20, 50, and $75 \mathrm{~m}$ setbacks, respectively).

Finally, three receptor setbacks were tested: 20, 50, and $75 \mathrm{~m}$. The results indicate that only the $75 \mathrm{~m}$ setback demonstrated a risk reduction magnitude comparable to nourishment + dune; however, the efficiency of the nourishment + dune was in general higher than the managed retreat. Only in S'Abanell, with higher topography and where the measure only consists of a dune without nourishment, was a greater risk reduction achieved through the $75 \mathrm{~m}$ setback.
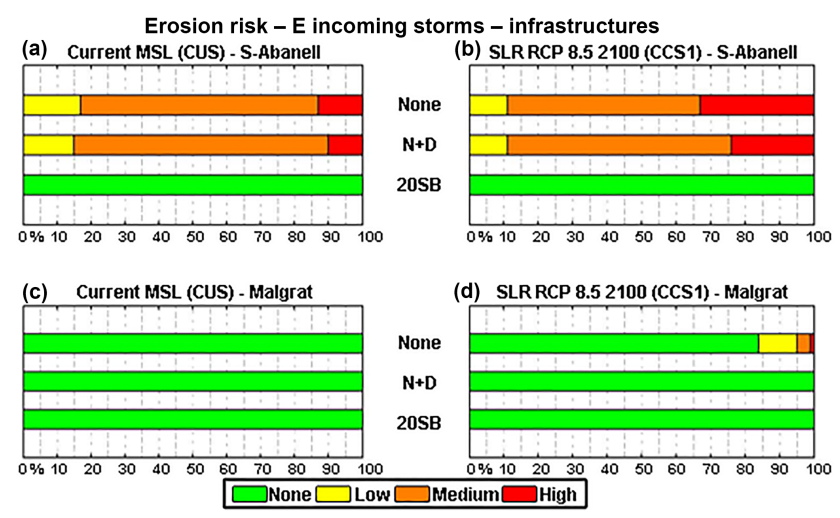

Figure 13. Distribution of Infrastructures at every level erosion risk: (a) current scenario at S'Abanell; (b) climate change scenario 1 (SLR) at S'Abanell; (c) current scenario at Malgrat; (d) climate change scenario 1 (SLR) at Malgrat. Each bar in a panel represents a risk reduction configuration ('"none"': no measure implemented; "N + D": nourishment and dune; "FRM": flood resilience measures; "20SB, 50SB, and 75SB": 20, 50, and 75 m setbacks, respectively).

Results for the erosion impact risk assessment showed similar results for the three analysed receptor categories and no significant differences between CUS and CC 2 or between $\mathrm{CC} 1$ and $\mathrm{CC} 3$. For simplicity, results related to Infrastructure (Fig. 13), for the CUS and CC1 scenarios are provided in the following.

Under the CUS, the promenade at the north of the river mouth is at significant risk $(70 \%$ at medium risk and $13 \%$ at high risk), whereas the road in Malgrat is potentially safe. In the CCS1 scenario, the assessment highlights that because of the increase of sea level and corresponding morphological accommodation, the percentage of promenade under high risk and therefore direct erosion at the toe increases up to $33 \%$, with some impact appearing on the road in Malgrat.

The assessment of the efficiency of the measures regarding erosion indicates that the nourishment + dune does not have a significant impact on reducing risk. In addition, the beach nourishment is regularly washed out in severe storm conditions. The only case where the nourishment plays some protective role is at the road in Malgrat, where the measure prevents the impact in CCS1. In contrast, receptor setback is $100 \%$ effective in dealing with the impact of erosion, and a $20 \mathrm{~m}$ retreat (measured from beach limit in current conditions) is enough to cope with risk under the present situation and for all future projected conditions at both sides of the river mouth.

\subsection{Lido degli Estensi-Spina}

The overall results for flooding and erosion risks on concessions are shown in Figs. 14 and 15. Focusing on the flooding risk (Fig. 14), the CUS evidenced noticeable impacts, with Lido di Spina presenting the larger number of receptors at 


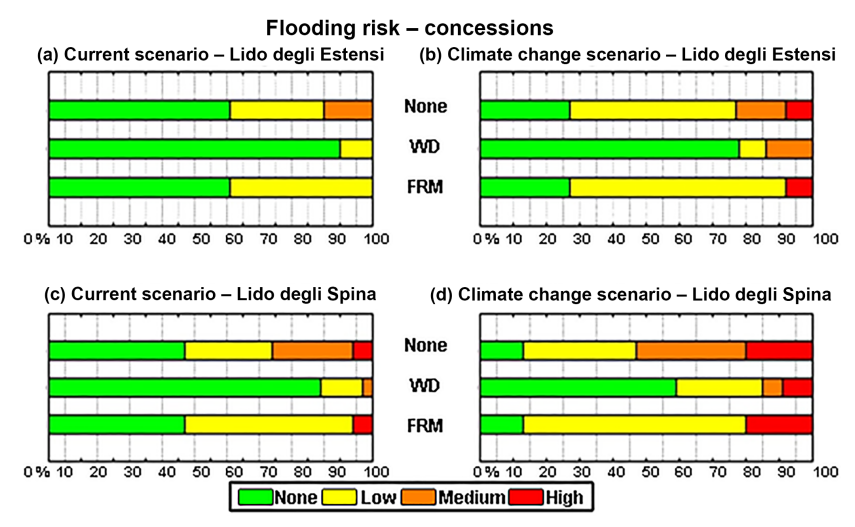

Figure 14. Distribution of concessions for every level of flooding risk. (a) Current scenario at Lido degli Estensi; (b) climate change scenario at Lido degli Estensi; (c) current scenario at Lido di Spina; (d) climate change scenario at Lido di Spina. Each bar in a panel represents a risk reduction configuration ("none": no measure implemented; "WD": winter dune; "FRM": flood resilience measures).

risk and with higher intensity. The presence of a CCS exacerbates expected impacts.

The winter dune system had a positive impact in all cases, with the number of concessions at risk decreasing to $10 \%$ (only low risk) at Lido degli Estensi and $13 \%$ at low and $3 \%$ at medium risk at Lido di Spina. This measure was also effective to reduce the risk under the CCS.

The flood resilience measures had positive effects on impacts by moving all receptors at medium risk to the low risk category. However, by definition, it had no effect on lowering the fraction of receptors presenting, in the current situation, low and high levels of risk.

With respect to erosion-induced impacts, obtained results indicate a lower level of risk than the identified for flooding, with only the 8 and $14 \%$ of concessions being at risk at Lido degli Estensi and Lido di Spina, respectively (Fig. 15). These percentages increase up to 11 and $30 \%$, respectively, when the CCS is considered.

The effectiveness of the winter dune system as a risk reduction measure is demonstrated by the observed decrease in the number of potentially damaged concessions at Lido di Spina under both climate scenarios. However, at Lido degli Estensi this measure increases the number of potentially damaged receptors. Simulation results show that when the dune is present with concessions close at its rear, and the storm overcomes the measure, water arrives with enough velocity to produce scouring at the first concessions.

A further step in the analysis of risk scenarios was undertaken using the BDN in reverse mode, i.e. looking at the distribution of the boundary conditions given a certain distribution of flood damage to concessions at Lido degli EstensiSpina, both with and without winter dune. Flood damage to concessions is constrained in the BDN to equal fractions of low, medium, and high risk. This can be understood as a
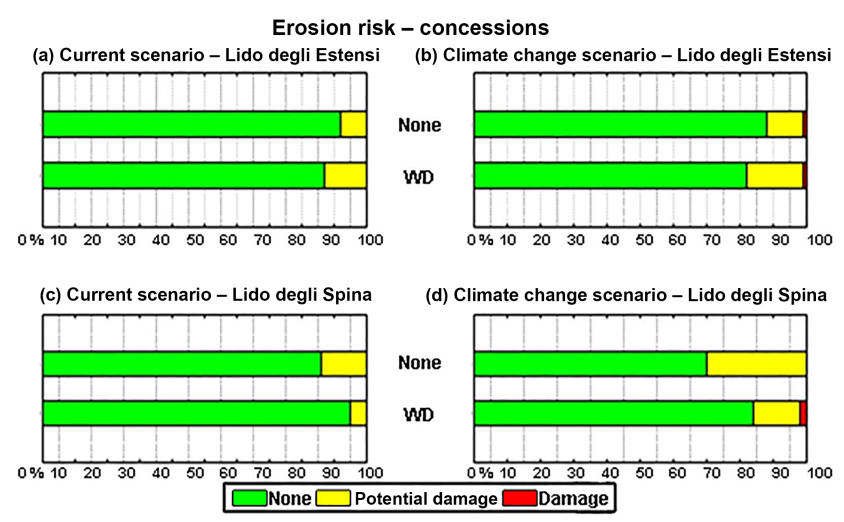

Figure 15. Distribution of concessions for every level of erosion risk. (a) Current scenario at Lido degli Estensi; (b) climate change scenario at Lido degli Estensi; (c) current scenario at Lido di Spina; (d) climate change scenario at Lido di Spina. Each bar in a panel represents a risk reduction configuration ("none": no risk reduction implemented; "WD": winter dune; "FRM": flood resilience measures).

qualitative scenario were all receptors suffer some damage, and the intensity of the damage is uniformly distributed. The BDN outputs the fractions of boundary conditions which are likely to produce the constrained impacts, according to the introduced data.

Notably, under current scenario and without measure, the Hs is distributed more uniformly compared to the TWL (Fig. 16), which demonstrates a strong increasing tendency. This indicates that compared to wave conditions, the water level is the main driver for flood impacts.

The results for the winter dune scenario showed that the largest fraction of conditions leading to flood damages to concessions are TWL $>1.45 \mathrm{~m}(93 \%)$ and $\mathrm{Hs}>4 \mathrm{~m}$ $(4<\mathrm{Hs}<5 \mathrm{~m}: 47 \% ; 5<\mathrm{Hs}<6 \mathrm{~m}$ : $43 \%)$. These results indicated that the winter dune is effective to minimise the consequences of coastal storms with $\mathrm{TWL}<1.45 \mathrm{~m}$ and $\mathrm{Hs}<4 \mathrm{~m}$ in the current situation.

When the analysis was performed under the CCS (Fig. 17) the situation without measure demonstrated an even lower influence of $\mathrm{Hs}$ on flood consequences to concessions, since a more uniform distribution of this variable is obtained. As expected, the relative SLR ( $+0.3 \mathrm{~m}$; RCP8.5 by 2050) increased the risk of lower-intensity storms. Thus, in general, under the CCS, all storm combinations generated flood consequences to concessions.

The results for the winter dune in the CCS showed that the influence of the dune system is less effective than in current conditions. Lower-intensity storms can now lead to flood damages to concessions (TWL $<1.45 \mathrm{~m}$ : $25 \%$; $\mathrm{Hs}<4 \mathrm{~m}$ : $32 \%$ ). This explains the observed decrease in effectiveness of the measure in future conditions when compared to present conditions. 

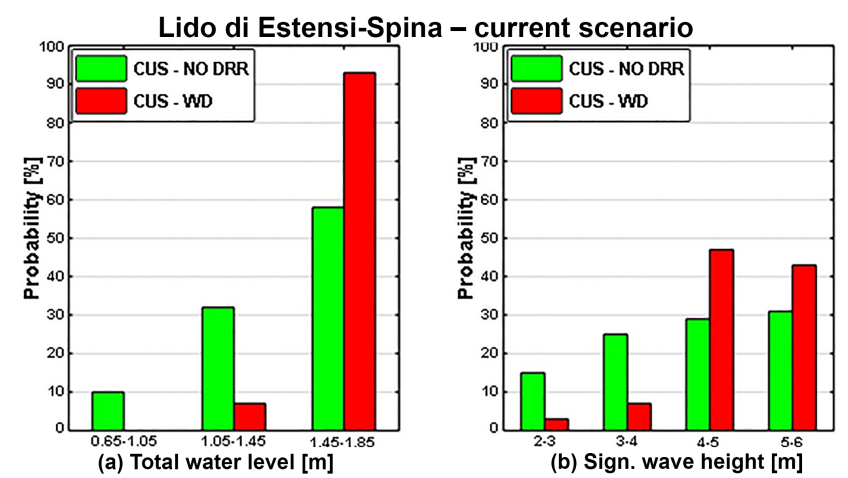

Figure 16. Distribution of boundary conditions (a TWL and b $\mathrm{Hs}$ ) for constrained uniform flood damages in the current scenario for Lido degli Estensi-Spina. The configuration without measures (green bars) and for the implementation of the winter dune (red bars) were compared.

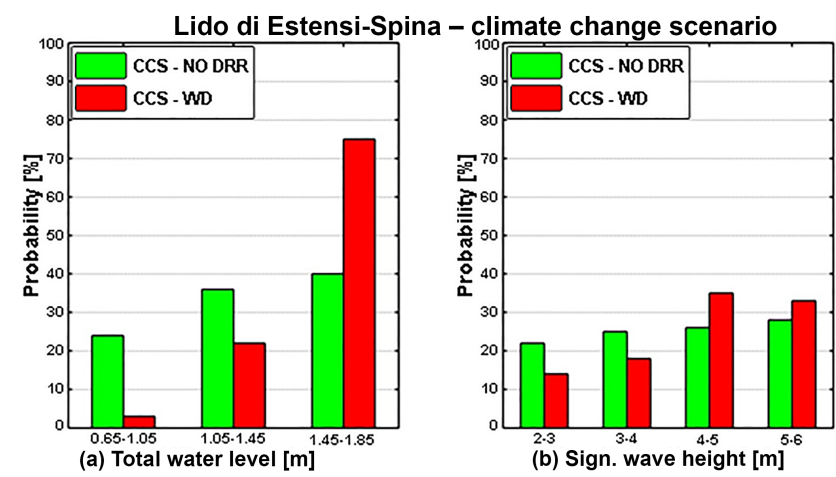

Figure 17. Distribution of boundary conditions (a TWL and b Hs) for constrained uniform flood damages in the climate change scenario for Lido degli Estensi-Spina. The configuration without measures (green bars) and under the implementation of the winter dune (red bars) were compared.

\section{Discussion}

The framework of the present study is appropriate for the prevention phase of the disaster management cycle. In this context, it has been applied to support decisions for coastal risk management by facilitating intercomparison of risk reduction strategic alternatives. This comparison was performed for a large set of simulations, covering many (current and future) conditions and multiple hazards. The presented work is part of a larger investigatory process (see Martinez et al., 2018) where stakeholders and end users were interviewed to select possible measures for critical coastal areas (i.e. local scale). The objective of the present work was to provide rather simple information on the efficiency of measures to be used in a participatory process (see Barquet and Cumiskey, 2018) aiming at selecting acceptable measures to be applied as part of an integrated local strategy for risk reduction. The analysis has some inherent uncertainties associated with the imple- mentation of the steps of the SPRC model, which are identified and discussed in what follows.

With respect to the definition of sources, the BN approach has been built by chosen storm variables limited to those previously identified as the most important to control the magnitude of storm-induced hazards at each site. Once identified, they were discretised in equal intervals covering the whole range of values observed so far. A limited number of combinations has been used to cover the most important storm classes in terms of induced hazards and damages (Armaroli et al., 2009, 2012; Mendoza et al., 2011). Increasing number of variables and/or variable resolution will allow us to better reproduce the inherent climate variability and to characterise better this source of uncertainty in the assessment. In spite of this, used values can be considered as representative for forcing source in both areas and, in this sense, they will allow us to use the framework to assess the efficiency of tested measures to reduce inundation and erosion risks for each given condition. No prior knowledge of storm characteristic variables was assumed, representing them with uniform distributions. Thus, the current application, the BDN, was essentially deterministic. This was enough to communicate scenarios and measure efficiencies to stakeholders by integrating the BDN in a multi-criteria analysis such as that presented in Barquet and Cumiskey (2018). In such multicriteria assessments, the BDN output is combined with information on additional elements required for decision-making such as economics, endurance, ecological, stakeholders' perception, allowing for the final evaluation of alternatives. As it has been mentioned before, the next step should be to reproduce the local maritime climate to analyse this performance, taking into account the relative frequency of each condition. In such a case, the $\mathrm{BN}$ approach would be fully probabilistic. In addition, using time series data on real historical events would reduce the uncertainties introduced by representing some events with synthetic design shapes.

Uncertainties associated with the pathway are related to the selection of the process-oriented models used to simulate induced hazards. In the current analysis, we have not considered this source of uncertainty since the framework is applied by using previously selected models and recommended damage curves. As it was mentioned in the method section, the selected model to simulate storm-induced hazards is XBeach (Roelvink et al., 2009), which is currently one of the most applied at the international level. Applied model setting has been selected for each case study based on local calibrations and validations for selected storm impacts. This step must be done prior to $\mathrm{BN}$ development since it will control the accuracy of hazard estimation and it is also a source of uncertainty. In any case, the methodology can easily deal with this source of uncertainty if simulations from multiple models or model settings are used to feed the BN.

Another point to be considered is that this assessment framework has been designed to analyse the storm-induced coastal response. This implies that used models do not fore- 
cast the coastal morphology at a given time (where it should be necessary to couple all governing processes) but predict the expected storm-induced changes for a given coastal configuration. As storm-induced hazards depend on existing morphology at the time of the impact (e.g. Cohn and Ruggiero, 2016), the initial morphology used in the model is also a source of uncertainty. To overcome this, a long-/mediumterm morphological model (Hanson et al., 2003; Lesser et al., 2004) could be used to forecast the future coastal morphology under a given climate scenario at a given time and then, to use it as the initial configuration to assess storminduced changes. This has been illustrated here by considering the change in estimated risks due to SLR in Tordera Delta. This approach can also be applied to assess the effects of consecutive storm impacts (Coco et al., 2014) by using estimated post-storm bed levels as pre-storm morphology for given storm combinations. Once this extra information is included in the $\mathrm{BN}$, the uncertainty associated to future shoreline configurations on assessed risks can be analysed.

Regarding receptors, their location and typology have little associated uncertainty, except for future projections, where it was not considered (i.e. type and location of receptors remain constant in time). Houses, promenades, and fixed elements were derived from accurate land-use and cadastral data available for the sites. Moreover, campsite elements were manually located and delimited from available GIS-based tools and raster imagery. In spite of this, some uncertainty associated with the mobility of campsite elements between seasons, as well as to land-use changes or new developments, remains. In the case of temporary elements, the worst case scenario was considered; i.e. they are assumed to be present at any space allocated to them. This implies that maximum potential damage was estimated. This could be modified by considering the existing time lag between intensive tourist use of beaches (and consequently in campsites or concessions) and storms seasonality (e.g. Valdemoro and Jiménez, 2006). The existing lag can be used to modify or reduce the exposure of this temporary elements to storm impacts.

With respect to the consequences, expected damages due to inundation have been estimated by using damage curves. Although this is a standard approach for this type of analysis (see e.g. Penning-Rowsell et al., 2013), the damage curves used have been recommended by Agència Catalana del 'Aigua (2014) and Scorzini and Frank (2015) for river flooding in Catalonia and Italy, respectively. The absence of specific damage curves estimated for analysed process and existing elements also introduces uncertainty, although in this case it is already assumed by the corresponding administrations since they are recommending its use. The equivalent for expected damages due to erosion was set in terms of an erosion buffer, which represents the protective function of the beach against the direct impact of waves. As it was previously shown, this buffer was selected specifically for each site and, similarly to damage curves, it must be defined according to local conditions.
Regarding the inclusion of the risk reduction measures in the analysis, it is assumed that protective strategies are completely and efficiently implemented when storm events occur. In the case of flood resilience measures, this implies that all existing elements in each site (from campsites to buildings) implemented flood-proofing measures. However, local, social, and economic conditions will influence its real implementation (see e.g. Bubeck et al., 2013) and, in any case, this assumption clearly overestimate its efficiency.

When setback definition and retreat is the adopted strategy, the used approach to characterise the initial coastal morphology also has implications on the results consideration. This implies that the effectiveness of the retreat is just measured with respect to the storm reach. To be efficient in time, the existence of any additional mid- and long-term background erosion, as it is the case of the Tordera site (Jiménez et al., 2018), should be included to properly define the required setback (e.g. Sano et al., 2011).

This also applies to infrastructural measures, which are considered to be implemented at the time of the storm impact. In the case of the combined nourishment-dune solution considered in the Tordera case, this would imply that to maintain its efficiency in time, the beach would have to be renourished after each storm impact to maintain the $50 \mathrm{~m}$ increase in beach width. This also affects the efficiency of the winter dune tested in the Italian case, which strictly depends on the beach width before the storm impact. In this sense, Harley and Ciavola (2013) indicate that the dune height and crest width required to protect the area should be designed differently for different coastal stretches along the study site. From the coastal manager standpoint, this implies that to properly assess their performance in the future, background processes must be considered to account additional losses in beach nourishment in the Tordera (e.g. Jiménez et al., 2011) or in beach width variations along the Italian case (Armaroli et al., 2012).

Assessed risks under current conditions at both locations are consistent with already observed impacts. At the Tordera site, erosion and direct wave impact problems are the main issue for campsites and existing infrastructures (Jiménez et al., 2011, 2017b). At the Italian case, flooding is the dominant hazard with assessed impacts being comparable with previous observations (e.g. Perini et al., 2016).

As a result of the combination of hazard and site characteristics, a notable increase of the assessed impacts is predicted for both sites when SLR is considered. At the Tordera delta, overall results indicate a doubling of expected flooding impacts. Moreover, erosion impacts will increase even further since the induced retreat will immediately imply an increase in receptor exposure. This behaviour is similar to the observed increase in damages due to the present background erosion, where campsites located in unprotected areas have been progressively losing space at the seaward boundary, and the existing promenade has suffered frequent damages during the last decades (Jiménez et al., 2011). At the Italian case 
study, SLR and subsidence effects are mainly identified in flooding risk which will be significantly larger. However, although erosion risk will also increase, it will remain relatively low. This lower increase is caused by both a closer future projection compared to Tordera and by the effect of not including the morphological response to SLR since, in this case, the future scenario was only characterised by increasing the position of the MSL.

When considering SLR-induced effects on time evolution of storm-induced risks, existing uncertainties must be also taken into account. Thus, the first uncertainty is related to the magnitude of the change itself. Here the RCP8.5 SLR projection was used, but other scenarios could be possible (Church et al., 2013). The other source of uncertainty is controlled by the way in which this forcing is translated into the system. In this work the Bruun rule was assumed to be valid and it was used to generate a morphological accommodation of the Tordera Delta site to SLR. Since there is no consensus on the best model to simulate this effect, other existing models and approaches (see e.g. Le Cozannet et al., 2014) could be tested and integrated in the $\mathrm{BN}$ to include this source of uncertainty. In any case, the effect of the uncertainty on the SLR projections may be larger than their associated morphological response.

In spite of the sources of uncertainty previously mentioned, this analysis has permitted us to identify the most harmful conditions to induce storm-related inundation and erosion risks at the two study sites, to identify which are the most affected receptors, and to compare the efficiency of different risk reduction strategies. This has been done by considering both hazards in a separated manner, which is an advantage for the manager since damage induced by erosion and inundation differs in characteristics and needs to be afforded in a specific manner. Although this can be a valuable tool for decision-making in storm-induced risk management, it must be further complemented with a similar analysis including the reproduction of the statistical structure of storms in combination with a socioeconomic valuation such as multi-criteria analysis to properly make final decisions. In this sense, this analysis can be used as the first step to identify the most relevant risks and strategies to be further tested.

\section{Conclusions}

In this paper, a methodological framework for storm-induced coastal risk management purposes developed within the framework of the RISC-KIT EU project was presented and applied in two sites in the NW Mediterranean and $\mathrm{N}$ Adriatic coasts. The study is based on the integration of the SPRC model in a BN-based approach. This was fed with a large number of numerical simulations obtained through process-oriented model chain able to simulate multiple storm-induced hazards at the receptor scale. The BN integrates impact results that individually account for all re- ceptors in the hinterland. Once developed, the BN can be regularly updated with additional simulations and further extended with new scenarios.

The presented application, a Bayesian-based decision network, has been fed with storms covering the range of representative conditions at both study sites and uniform distribution of source variables. This permitted us to assess in a deterministic way, the performance of different risk reduction strategies to individual hazards and under different climate scenarios.

In spite of not statistically mimicking the maritime climate, the approach demonstrated impact responses in the current situation in accordance with existing knowledge at both sites. Tordera Delta, which is characterised by quick and intense erosive responses to storms, showed greater impacts to erosion than Lido degli Estensi-Spina and they were essentially concentrated in infrastructure located just behind the beach. As expected, the flooding impact in the current situation is higher for receptors located closest to the shoreline or at the lowest elevation areas of the hinterland (i.e. concessions at Lido di Spina and campsites at Malgrat).

The estimated risk significantly increases for the climate change scenario. The morphological accommodation response to the projected MSL, which was only included at the Tordera Delta, was identified as a major process to be considered in the impact assessment to properly account for modifications in erosion and inundation hazards.

From the tested risk reduction strategies, the construction of artificial dunes was identified as very effective for inundation at both study sites, whereas its efficiency for managing erosion was lower. In contrast, and as expected, setback definition and managed retreat seems to be the best option to tackle the impacts of erosion.

Finally, the developed framework has proven to be efficient to analyse storm-induced risks and strategies to cope with them. Moreover, a series of elements to be addressed to further improve it and to extend its applicability have been identified and discussed. In this sense, the $\mathrm{BN}$ approach is a versatile tool to make robust comparisons across different conditions.

Data availability. Spanish wave data have been supplied by Puertos del Estado (Spanish Ministry of Public Works) and are available directly from them (http://www.puertos.es/es-es/oceanografia/ Paginas/portus.aspx) (Puertos del Estado, 2018). Aerial photographs and topographic data have been obtained from the Institut Cartogràfic i Geològic de Catalunya (government of Catalonia) and are available directly from them (http://www.icc.cat/vissir/) (ICC, 2018).

Italian aerial photographs are available from http://geoportale. regione.emilia-romagna.it/it (Regione Emilia-Romagna, 2018). Storm information of the Italian case and damage data for both study sites can be obtained from the Risc-kit project database (http: //risckit.cloudapp.net/risckit/\#/). 
Numerical model simulations used to build the BN are not freely available but reasonably argued petitions can be directed to Marc Sanuy (Spanish case study) and Enrico Duo (Italian case study).

Author contributions. MSV and ED adapted and ran the tool at the Tordera Delta and Lido degli Estensi-Spina sites, respectively, and prepared the manuscript with contributions from all co-authors. WSJ developed the generic tool and helped with the implementation. JAJ and PC supervised the work and critically revised the manuscript.

Competing interests. The authors declare that they have no conflict of interest.

Acknowledgements. This work was conducted in the framework of the RISC-KIT (GA 603458) and PaiRisClima (CGL2014-55387-R) research projects funded by the EU FP7 and Spanish Ministry of Economy and Competitiveness and Feder, respectively. Marc Sanuy was supported by a PhD grant from the Spanish Ministry of Education, Culture and Sport. Enrico Duo was supported by the Consorzio Futuro in Ricerca (Ferrara, Italy) through the RISC-KIT project and a PhD grant at the Department of Physics and Earth Science of the University of Ferrara. During the preparation of the paper, Marc Sanuy and José A. Jiménez were supported by the M-CostAdapt (CTM2017-83655-C2-1-R) research project (MINECO/AEI/FEDER, UE) and Enrico Duo and Paolo Ciavola were supported by the H2020 ANYWHERE Project (GA700099). The authors thank the Institut Cartogràfic i Geològic de Catalunya for supplying aerial photographs and lidar data and Puertos del Estado of the Spanish Ministry of Public Works for supplying wave and water level data. The authors thank the Servizio Geologico Sismico e dei Suoli of the Emilia-Romagna Region, in particular Luisa Perini, for providing input data and comments on the outcomes. The authors are grateful to Clara Armaroli, for helping in the application of the methodology at the Italian site, and to the people working on RISC-KIT, for their support during the entire project.

Edited by: Bruno Merz

Reviewed by: three anonymous referees

\section{References}

Agència Catalana de l'Aigua: Pla especial d'emergències per inundacions (INUNCAT), available at: http://interior.gencat.cat/ web/.content/home/030_arees_dactuacio/proteccio_civil/plans_ de_proteccio_civil/plans_de_proteccio_civil_a_catalunya/ documents/inuncat.pdf (last access: May 2018), 2014.

Armaroli, C. and Duo, E.: Validation of the Coastal Storm Risk Assessment Framework along the Emilia-Romagna coast, Coast. Eng., 134, 159-167, https://doi.org/10.1016/j.coastaleng.2017.08.014, 2018.

Armaroli, C., Ciavola, P., Masina, M., and Perini, L.: Run-up computation behind emerged breakwaters for marine storm risk assessment, J. Coast. Res., 56, 1612-1616, 2009.
Armaroli, C., Ciavola, P., Perini, L., Calabrese, L., Lorito, S., Valentini, A., and Masina, M.: Critical storm thresholds for significant morphological changes and damage along the EmiliaRomagna coastline, Italy, Geomorphology, 143-144, 34-51, https://doi.org/10.1016/j.geomorph.2011.09.006, 2012.

Barquet, K. and Cumiskey, L.: Using participatory Multi-Criteria Assessments for assessing disaster risk reduction measures. Coast. Eng., 134, 93-102, https://doi.org/10.1016/j.coastaleng.2017.08.006, 2018.

Bertin, X., Bruneau, N., Breilh, J. F., Fortunato, A. B., and Karpytchev, M.: Importance of wave age and resonance in storm surges: The case Xynthia, Bay of Biscay, Ocean Model., 42, 1630, https://doi.org/10.1016/j.ocemod.2011.11.001, 2012.

Bertoni, D., Armaroli, C., and Ciavola, P.: Fast retreat of a barrier system due to reduced sediment supply (Bellocchio, Northern Adriatic Sea, Italy), in Coastal and Maritime Mediterranean Conference, 3rd edn., Ferrara, Italy 7-10, 2015.

Bertotti, L., Bidlot, J. R., Bunney, C., Cavaleri, L., Delli Passeri, L., Gomez, M., Lefèvre, J. M., Paccagnella, T., Torrisi, L., Valentini, A., and Vocino, A.: Performance of different forecast systems in an exceptional storm in the Western Mediterranean Sea, Q. J. Roy. Meteorol. Soc., 138, 34-55, https://doi.org/10.1002/qj.892, 2012.

Beven II, J. L., Avila, L. A., Blake, E. S., Brown, D. P., Franklin, J. L., Knabb, R. D., Pasch, R. J., Rhome, J. R., and Stewart, S. R.: Atlantic Hurricane Season of 2005, Mon. Weather Rev., 136, 1109-1173, https://doi.org/10.1175/2007MWR2074.1, 2008.

Billi, P. and Rinaldi, M.: Human impact on sediment yield and channel dynamics in the Arno River basin (central Italy), in Human Impact on Erosion and Sedimentation, Proceedings of Rabat Symposium S6, April 1997, IAHS Press, Institute of Hydrology, Wallingford, Oxfordshire, UK, 301-311, 1997.

Booij, N., Holthuijsen, L. H., and Ris, R. C.: The SWAN wave model for shallow water, Proc. 25th Int. Conf. Coastal Eng., Orlando, Florida, USA, 668-676, 1996.

Bosom, E.: Coastal vulnerability to storms at different time scales: application to the Catalan coast, Universitat Politècnica de Catalunya, PhD Thesis, 2014.

Bruun, P.: Sea-level rise as a cause of shore erosion, J. Waterw. Harb. Div., 88, 117-132, 1962.

Bubeck, P., Botzen, W. J. W., Kreibich, H., and Aerts, J. C. J. H.: Detailed insights into the influence of flood-coping appraisals on mitigation behaviour, Global Environ. Chang., 23, 1327-1338, 2013.

Carley, J. T. and Cox, R. J.: A Methodology for Utilising TimeDependent Beach Erosion Models for Design Events, in: Coasts \& Ports 2003 Australasian Conference: Proceedings of the 16th Australasian Coastal and Ocean Engineering Conference, the 9th Australasian Port and Harbour Conference and the Annual New Zealand Coastal Society Conference, edited by: Kench, P. S., and Hume, T. M., 587-595, 2003.

Casas-Prat, M. and Sierra, J. P.: Trend analysis of wave direction and associated impacts on the Catalan coast, Clim. Change, 115, 667-691, https://doi.org/10.1007/s10584-012-0466-9, 2012.

Church, J. A., Clark, P. U., Cazenave, A., Gregory, J. M., Jevrejeva, S., Levermann, A., Merrifield, M. A., Milne, G. A., Nerem, R. S., Nunn, P. D., Payne, A. J., and Pfeffer, W. T.: Sea-Level Rise by 2100, Science, 342, 1445, https://doi.org/10.1126/science.342.6165.1445-a, 2013. 
Ciavola, P., Armaroli, C., Chiggiato, J., Valentini, A., Deserti, M., Perini, L., and Luciani, P.: Impact of storms along the coastline of Emilia-Romagna: the morphological signature on the Ravenna coastline (Italy), J. Coast. Res., 50, 540-544, 2007.

Ciavola, P., Ferreira, O., Haerens, P., Van Koningsveld, M., Armaroli, C., and Lequeux, Q.: Storm impacts along European coastlines, Part 1: The joint effort of the MICORE and ConHaz Projects, Environ. Sci. Policy, 14, 912-923, https://doi.org/10.1016/j.envsci.2011.05.011, 2011a.

Ciavola, P., Ferreira, O., Haerens, P., Van Koningsveld, M., and Armaroli, C.: Storm impacts along European coastlines. Part 2: Lessons learned from the MICORE project, Environ. Sci. Policy, 14, 924-933, https://doi.org/10.1016/j.envsci.2011.05.009, $2011 b$.

Ciavola, P., Harley, M. D., and den Heijer, C.: The RISC-KIT storm impact database: a new tool in support of DRR, Coast. Eng., 134, 24-32, https://doi.org/10.1016/j.coastaleng.2017.08.016, 2018.

Coco, G., Senechal, N., Rejas, A., Bryan, K. R., Capo, S., Parisot, J. P., and MacMahan, J. H.: Beach response to a sequence of extreme storms, Geomorphology, 204, 493-501, 2014.

Cohn, N. and Ruggiero, P.: The influence of seasonal to interannual nearshore profile variability on extreme water levels: Modeling wave runup on dissipative beaches, Coast. Eng., 115, 7992, 2016.

Conte, D. and Lionello, P.: Characteristics of large positive and negative surges in the Mediterranean Sea and their attenuation in future climate scenarios, Glob. Planet. Change, 111, 159-173, https://doi.org/10.1016/j.gloplacha.2013.09.006, 2013.

Corbella, S. and Stretch, D. D.: Multivariate return periods of sea storms for coastal erosion risk assessment, Nat. Hazards Earth Syst. Sci., 12, 2699-2708, https://doi.org/10.5194/nhess12-2699-2012, 2012.

FLOODsite: Language of risk: Project Definitions, edited by: Samuels, P. and Gouldby, B., Wallingford, Oxfordshire, UK, available at: http://floodsite.net/html/partner_area/project_docs/ T32_04_01_FLOODsite_Language_of_Risk_D32_2_v5_2_P1. pdf (last access: 31 August 2017), 2009.

Guedes-Soares, C., Weisse, R., Carretero, J. C., and Alvarez, E.: A 40 years hindcast of wind, sea level and waves in European waters, in 21st International Conference on Offshore Mechanics and Arctic Engineering, 2, 669-675, ASME, Oslo, Norway, 2002.

Gutierrez, B. T., Plant, N. G., and Thieler, E. R.: A Bayesian network to predict coastal vulnerability to sea level rise, J. Geophys. Res.-Earth, 116, 1-15, https://doi.org/10.1029/2010JF001891, 2011.

Hanson, H., Aarninkhof, S., Capobianco, M., Jiménez, J. A., Larson, M., Nicholls, R. J., Plant, N. G., Southgate, H. N., Steetzel, H. J., Stive, M. J. F., and de Vriend, H. J.: Modelling of coastal evolution on yearly to decadal time scales, J. Coastal Res., 19, 790-811, 2003.

Harley, M.: DuneMaker 2.0: A MATLAB tool to simulate artifitial dunes using XBeach, https://doi.org/10.13140/2.1.3941.7120, 2014

Harley, M. and Ciavola, P.: Managing local coastal inundation risk using real-time forecasts and artificial dune placements, Coast. Eng., 77, 77-90, https://doi.org/10.1016/j.coastaleng.2013.02.006, 2013.
Harley, M., Armaroli, C., and Ciavola, P.: Evaluation of XBeach predictions for a real-time warning system in Emilia-Romagna, Northern Italy, J. Coast. Res., 64, 1861-1865, 2011.

Harley, M. D., Valentini, A., Armaroli, C., Perini, L., Calabrese, L., and Ciavola, P.: Can an early-warning system help minimize the impacts of coastal storms? A case study of the 2012 Halloween storm, northern Italy, Nat. Hazards Earth Syst. Sci., 16, 209-222, https://doi.org/10.5194/nhess-16-209-2016, 2016.

ICC: Vissir: Cartographic and topographic dataset, Institut Cartogràfic i Geològic de Catalunya, http://www.icc.cat/vissir/, last access: May 2018.

IDROSER: Progetto di Piano per la difesa del mare e la riqualificazione ambientale del litorale della Regione Emilia-Romagna, Bologna, Italy, 1996.

IPCC: Managing the risks of extreme events and disasters to advance climate change adaptation, A Special Report of Working Groups I and II of the Intergovernmental Panel on Climate Change, edited by: Field, C. B., Barros, V., Stocker, T. F., Qin, D., Dokken, D. J., Ebi, K. L., Mastrandrea, M. D., Mach, K. J., Plattner, G.-K., Allen, S. K., Tignor, M., and Midgley, P. M., Cambridge University Press, Cambridge, UK, New York, NY, USA, 2012.

IPCC: Climate Change 2013: The Physical Science Basis, Contribution of Working Group I to the Fifth Assessment Report of the Intergovernmental Panel on Climate Change, edited by: Stocker, T. F., Qin, D., Plattner, G.-K., Tignor, M., Allen, S. K., Boschung, J., Nauels, A., Xia, Y., Bex, V., and Midgley, P. M., Cambridge University Press, Cambridge, UK, New York, NY, USA, 2013.

Jäger, W. S., Christie, E. K., Hanea, A. M., den Heijer, C., and Spencer, T.: A Bayesian network approach for coastal risk analysis and decision making, Coast. Eng., 134, 48-61, https://doi.org/10.1016/j.coastaleng.2017.05.004, 2018.

Jensen, F. V.: An introduction to Bayesian networks, UCL Press, London, UK, 1996.

Jiménez, J. A., Gracia, V., Valdemoro, H. I., Mendoza, E. T., and Sánchez-Arcilla, A.: Managing erosion-induced problems in NW Mediterranean urban beaches, Ocean Coast. Manag., 54, 907918, https://doi.org/10.1016/j.ocecoaman.2011.05.003, 2011.

Jiménez, J. A., Sancho-García, A., Bosom, E., Valdemoro, H. I., and Guillén, J.: Storm-induced damages along the Catalan coast (NW Mediterranean) during the period 1958-2008, Geomorphology, 143-144, 24-33, https://doi.org/10.1016/j.geomorph.2011.07.034, 2012.

Jiménez, J. A., Valdemoro, H. I., Bosom, E., Sánchez-Arcilla, A., and Nicholls, R. J.: Impacts of sea-level rise-induced erosion on the Catalan coast, Reg. Environ. Chang., 17, 593-603, https://doi.org/10.1007/s10113-016-1052-x, 2017.

Jiménez, J. A., Sanuy, M., Ballesteros, C., and Valdemoro, H. I.: The Tordera Delta, a hotspot to storm impacts in the coast northwards of Barcelona (NW Mediterranean), Coast. Eng., 134, 148158, https://doi.org/10.1016/j.coastaleng.2017.08.012, 2018.

Kolen, B., Slomp, R., and Jonkman, S. N.: The impacts of storm Xynthia February 27-28, 2010 in France: Lessons for flood risk management, J. Flood Risk Manag., 6, 261-278, https://doi.org/10.1111/jfr3.12011, 2013.

Kunz, M., Mühr, B., Kunz-Plapp, T., Daniell, J. E., Khazai, B., Wenzel, F., Vannieuwenhuyse, M., Comes, T., Elmer, F., Schröter, K., Fohringer, J., Münzberg, T., Lucas, C., and Zschau, J.: Investigation of superstorm Sandy 2012 in a multi- 
disciplinary approach, Nat. Hazards Earth Syst. Sci., 13, 25792598, https://doi.org/10.5194/nhess-13-2579-2013, 2013.

Lauritzen, S. L. and Spiegelhalter, D. J.: Local Computations with Probabilities on Graphical Structures and Their Application to Expert Systems, J. R. Stat. Soc. B, 50, 157-224, 1988.

Le Cozannet, G., Garcin, M., Yates, M., Idier, D., and Meyssignac, B.: Approaches to evaluate the recent impacts of sea-level rise on shoreline changes, Earth Sci. Rev., 138, 47-60, https://doi.org/10.1016/j.earscirev.2014.08.005, 2014.

Lesser, G. R., Roelvink, J. V., Van Kester, J. A. T. M., and Stelling, G. S.: Development and validation of a three-dimensional morphological model, Coast. Eng., 51, 883-915, 2004.

Lionello, P., Boldrin, U., and Giorgi, F.: Future changes in cyclone climatology over Europe as inferred from a regional climate simulation, Clim. Dynam., 30, 657-671, https://doi.org/10.1007/s00382-007-0315-0, 2008.

Martinez, G., Armaroli, C., Costas, S., Harley, M. D., and Paolisso, M.: Experiences and results from interdisciplinary collaboration: Utilizing qualitative information to formulate disaster risk reduction measures for coastal regions, Coast. Eng., 134, 62-72, https://doi.org/10.1016/j.coastaleng.2017.09.010, 2018.

Masina, M., Lamberti, A., and Archetti, R.: Coastal flooding: A copula based approach for estimating the joint probability of water levels and waves, Coast. Eng., 97, 37-52, https://doi.org/10.1016/j.coastaleng.2014.12.010, 2015.

McCall, R. T., Van Thiel de Vries, J. S. M., Plant, N. G., Van Dongeren, A. R., Roelvink, J. A., Thompson, D. M., and Reniers, A. J. H. M.: Two-dimensional time dependent hurricane overwash and erosion modeling at Santa Rosa Island, Coast. Eng., 57, 668683, https://doi.org/10.1016/j.coastaleng.2010.02.006, 2010.

Mendoza, E. T. and Jiménez, J.: Clasificación de tormentas costeras para el litoral catalán (Mediterráneo NO), Ing. Hidr. en México, 2, 23-34, 2008.

Mendoza, E. T., Jimenez, J. A., and Mateo, J.: A coastal storms intensity scale for the Catalan sea (NW Mediterranean), Nat. Hazards Earth Syst. Sci., 11, 2453-2462, https://doi.org/10.5194/nhess-11-2453-2011, 2011.

Narayan, S., Nicholls, R. J., Clarke, D., Hanson, S., Reeve, D., Horrillo-Caraballo, J., le Cozannet, G., Hissel, F., Kowalska, B., Parda, R., Willems, P., Ohle, N., Zanuttigh, B., Losada, I., Ge, J., Trifonova, E., Penning-Rowsell, E., and Vanderlinden, J. P.: The SPR systems model as a conceptual foundation for rapid integrated risk appraisals: Lessons from Europe, Coast. Eng., 87, 15-31, https://doi.org/10.1016/j.coastaleng.2013.10.021, 2014.

Nordstrom, K. F., Armaroli, C., Jackson, N. L., and Ciavola, P.: Opportunities and constraints for managed retreat on exposed sandy shores: Examples from EmiliaRomagna, Italy, Ocean Coast. Manag., 104, 11-21, https://doi.org/10.1016/j.ocecoaman.2014.11.010, 2015.

Oumeraci, H., Kortenhaus, A., Burzel, A., Naulin, M., Dassanayake, D. R., Jensen, J., Wahl, T., Mudersbach, C., Gönnert, G., Gerkensmeier, B., Fröhle, P., and Ujeyl, G.: XtremRisK - Integrated Flood Risk Analysis for Extreme Storm Surges at Open Coasts and in Estuaries: Methodology, Key Results and Lessons Learned, Coast. Eng. J., 57, 1540001, https://doi.org/10.1142/S057856341540001X, 2015.

Pearl, J.: Probabilistic reasoning in intelligent systems: networks of plausible inference, Morgan Kaufmann, San Francisco, California, USA, 1988.
Penning-Rowsell, E. C., Priest, S. J., Parker, D. J., Morris, J., Tunstall, S. M., Viavattene, C., Chatterton, J., and Owen, D.: Flood and coastal erosion risk management: a manual for economic appraisal, Routledge, Taylor \& Francis, London, 2013.

Penning-Rowsell, E. C., De Vries, W. S., Parker, D. J., Zanuttigh, B., Simmonds, D., Trifonova, E., Hissel, F., Monbaliu, J., Lendzion, J., Ohle, N., Diaz, P., and Bouma, T.: Innovation in coastal risk management: An exploratory analysis of risk governance issues at eight THESEUS study sites, Coast. Eng., 87, 210-217, https://doi.org/10.1016/j.coastaleng.2013.12.005, 2014.

Perini, L., Calabrese, L., Deserti, M., Valentini, A., Ciavola, P., and Armaroli, C.: Le mareggiate e gli impatti sulla costa in EmiliaRomagna 1946-2010, ARPA Emilia-Romagna, Bologna, Italy, 2011.

Perini, L., Calabrese, L., Lorito, S., and Luciani, P.: Costal flood risk in Emilia-Romagna (Italy): the sea storm of February 2015, in Coastal and Maritime Mediterranean Conference, 3rd edn., Ferrara, Italy, 225-230, 2015.

Perini, L., Calabrese, L., Salerno, G., Ciavola, P., and Armaroli, C.: Evaluation of coastal vulnerability to flooding: comparison of two different methodologies adopted by the EmiliaRomagna region (Italy), Nat. Hazards Earth Syst. Sci., 16, 181194, https://doi.org/10.5194/nhess-16-181-2016, 2016.

Plant, N. G., Thieler, E. R., and Passeri, D. L.: Coupling centennialscale shoreline change to sea-level rise and coastal morphology in the Gulf of Mexico using a Bayesian network, Earth's Future, 4, 143-158, 2016.

Plomaritis, T. A., Costas, S., and Ferreira, Ó.: Use of a Bayesian Network for coastal hazards, impact and disaster risk reduction assessment at a coastal barrier (Ria Formosa, Portugal), Coast. Eng., 134, 134-147, https://doi.org/10.1016/j.coastaleng.2017.07.003, 2018.

Poelhekke, L., Jäger, W. S., van Dongeren, A., Plomaritis, T. A., McCall, R., and Ferreira, Ó.: Predicting coastal hazards for sandy coasts with a Bayesian Network, Coast. Eng., 118, 21-34, https://doi.org/10.1016/j.coastaleng.2016.08.011, 2016.

Preciso, E., Salemi, E., and Billi, P.: Land use changes, torrent control works and sediment mining: Effects on channel morphology and sediment flux, case study of the Reno River (Northern Italy), Hydrol. Process., 26, 1134-1148, https://doi.org/10.1002/hyp.8202, 2012.

Puertos del Estado (Spanish Ministry of Public Works): Oceanografic Data, available at: http://www.puertos.es/es-es/ oceanografia/Paginas/portus.aspx, last access: May 2018.

Ratsimandresy, A. W., Sotillo, M. G., Carretero Albiach, J. C., Álvarez Fanjul, E., and Hajji, H.: A 44-year high-resolution ocean and atmospheric hindcast for the Mediterranean Basin developed within the HIPOCAS Project, Coast. Eng., 55, 827-842, https://doi.org/10.1016/j.coastaleng.2008.02.025, 2008.

Regione Emilia-Romagna: Geoportale, available at: http://geoportale.regione.emilia-romagna.it/it, last access: May 2018.

Regione Emilia-Romagna, Servizio Geologico Sismico e dei Suoli: Il sistema mare-costa dell'Emilia-Romagna, edited by: Perini, L. and Calabrese, L., Pendragon Monographies, Bologna, 240 pp., 2010 . 
Roelvink, D. and Reniers, A.: Advances in Coastal and Ocean Engineering, Vol. 12, A Guide to Modeling Coastal Morphology, 2012.

Roelvink, D., Reniers, A., van Dongeren, A., van Thiel de Vries, J., McCall, R., and Lescinski, J.: Modelling storm impacts on beaches, dunes and barrier islands, Coast. Eng., 56, 1133-1152, https://doi.org/10.1016/j.coastaleng.2009.08.006, 2009.

Sanuy, M. and Jiménez, J. A.: On the variability of extreme storminduced hazards to wave direction changes in a curvilinear sandy coast, Coast. Eng,. submitted, 2018

Sardá, R., Conde, R., Casadesús, M., Sánchez, A., and Pablo, J.: Erosión en las playas y gestión desintegrada: la problemática actual de la playa de S' Abanell, in Hacia un nuevo modelo integral de gestión de playas, Documenta Universitaria, Girona, 51-71, 2013.

Sano, M., Jiménez, J. A., Medina, R., Stanica, A., S-Arcilla, A., and Trumbic, I.: The role of coastal setbacks in the context of coastal erosion and climate change, Ocean Coast. Manage., 54, 943-950, 2011.

Scorzini, A. R. and Frank, E.: Flood damage curves: New insights from the 2010 flood in Veneto, Italy, J. Flood Risk Manag., 1-12, https://doi.org/10.1111/jfr3.12163, 2015.

Spencer, T., Brooks, S. M., Evans, B. R., Tempest, J. A., and Möller, I.: Southern North Sea storm surge event of 5 December 2013: Water levels, waves and coastal impacts, Earth-Sci. Rev., 146, 120-145, https://doi.org/10.1016/j.earscirev.2015.04.002, 2015.

Sutherland, J., Peet, A., and Soulsby, R.: Evaluating the performance of morphological models, Coast. Eng., 51, 917-939, 2004.

Sytnik, O. and Stecchi, F.: Disappearing coastal dunes: tourism development and future challenges, a case-study from Ravenna, Italy, J. Coast. Conserv., 19, 715-727, https://doi.org/10.1007/s11852-014-0353-9, 2014.

Taramelli, A., Di Matteo, L., Ciavola, P., Guadagnano, F., and Tolomei, C.: Temporal evolution of patterns and processes related to subsidence of the coastal area surrounding the Bevano River mouth (Northern Adriatic) - Italy, Ocean Coast. Manag., 108, 74-88, https://doi.org/10.1016/j.ocecoaman.2014.06.021, 2015.
Trembanis, A. C., Duo, E., Dohner, S., Grottoli, E., and Ciavola, P.: Quick Response Assessment of the Impact of an Extreme Storm Combining Aerial Drone and RTK GPS, Nat. Hazards Earth Syst. Sci. Discuss., https://doi.org/10.5194/nhess-2017-337, in review, 2017.

Trigo, I. F., Bigg, G. R., and Davies, T. D.: Climatology of Cyclogenesis Mechanisms in the Mediterranean, Mon. Weather Rev., 130, 549-569, https://doi.org/10.1175/15200493(2002)130<0549:COCMIT>2.0.CO;2, 2002.

Valdemoro, H. I. and Jiménez, J. A.: The Influence of Shoreline Dynamics on the Use and Exploitation of Mediterranean Tourist Beaches, Coast. Manage., 34, 405-423, 2016.

Van Dongeren, A., Ciavola, P., Martinez, G., and Viavattene, C.: Introduction to RISC-KIT: Resilienceincreasing strategies for coasts, Coast. Eng., 134, 2-9, https://doi.org/10.1016/j.coastaleng.2017.10.007, 2018.

Van Verseveld, H. C. W., Van Dongeren, A. R., Plant, N. G., Jäger, W. S., and den Heijer, C.: Modelling multihazard hurricane damages on an urbanized coast with a Bayesian Network approach, Coast. Eng., 103, 1-14, https://doi.org/10.1016/j.coastaleng.2015.05.006, 2015.

Vojinovic, Z., Abebe, Y., Sanchez, A., Medina Pena, N., Nikolic, I., Monojlovic, N., Makropoulos, C., Pelling, M., and Abbott, M.: Holistic flood risk assessment in coastal areas - the PEARL approach, in 11th International Conference on Hydroinformatics, 1-8, CUNY Academic Works, New York City, USA, 2014.

Vousdoukas, M. I., Voukouvalas, E., Annunziato, A., Giardino, A., and Feyen, L.: Projections of extreme storm surge levels along Europe, Clim. Dynam., 47, 3171-3190, https://doi.org/10.1007/s00382-016-3019-5, 2016.

Zanuttigh, B., Simcic, D., Bagli, S., Bozzeda, F., Pietrantoni, L., Zagonari, F., Hoggart, S., and Nicholls, R. J.: THESEUS decision support system for coastal risk management, Coast. Eng., 87, 218-239, https://doi.org/10.1016/j.coastaleng.2013.11.013, 2014. 